\title{
pH-Sensitive Nitroxide Radicals for Studying Inorganic and Organo-Inorganic Materials and Systems
}

\author{
Elena Kovaleva and Leonid Molochnikov \\ Additional information is available at the end of the chapter
}

http://dx.doi.org/10.5772/39119

\section{Introduction}

Many inorganic materials are widely used as adsorbents and catalysts. For example, silica gels efficiently absorb vapors and gases in chemical reactors and are applied as filters for the purification of mineral oils and water (Buyanov, 1998). Different aluminum oxide modifications show good adsorption and catalytic properties in many organic reactions due to the presence of active sites on their surface (Lisichkin et al., 2003). $\mathrm{TiO}_{2}$ gels are widely used in heterogeneous catalysis owing to their enhanced chemical stability, the accessibility of active sites on their surface throughout the reaction volume, simplicity of reaction product separation, and the feasibility of repeated regeneration (Petrov et al., 1998).

The efficiency of these materials mainly depends on the degree of surface development, texture and structural characteristics, availability of active centers, and possibly medium acidity near these centers. The specific surface diminishes on drying in any procedure for the preparation of xerogels. It can be maintained constant by a number of methods, including the use of additions (Ur'ev \& Potanin, 1992), for example, powder cellulose (PC) (Shishmakov et al., 2007). Cellulose is a linear high molecular polysaccharide, which forms rigid chain structures due to the inter-molecular hydrogen bonding. It functions in nature as an agent that imparts high mechanical stability to plant tissues (Nikitin, 1962). The deposition of $\mathrm{SiO}_{2}$ and $\mathrm{TiO}_{2}$ xerogels on the PC surface affords composite materials (CMs) with a high dispersity of particles (Shishmakov et al., 2010).

The use of hybrid organo-inorganic materials as supports is a new area in the development of new metal-containing catalytic materials. It allows to obtain supports with specific surfaces that are capable of retaining the metallic component of a catalytic system more strongly. 
Chitosan, poly-D- $\beta$-glucosamine, is a commercially available amino polymer that is a perfect complexing agent, due to the strong donor properties of both the amino and hydroxyl groups (Varma et al., 2004). Chitosan is thus widely used in obtaining various catalytic materials, including those containing $\mathrm{Au}^{0}$ that are used in the hydroamination of alkenes (Corma et al., 2007); $\mathrm{Pd}^{0}$ used for the reduction of ketones (Yin et al., 1999); the $\mathrm{Pd}^{0}-\mathrm{Ni}^{0}$ bimetallic system, used for carbonylation (Zhang \& Xia, 2003); Os (VIII), used for hydroxylation (Huang et al., 2003); $\mathrm{Co}^{2+}$, used for hydration (Xue et al., 2004); and $\mathrm{Cu}^{2+}$, used for the oxidation of catecholamines (Paradossi et al., 1998).

$\mathrm{SiO}_{2}$ is usually used as the inorganic component for these systems. The obtained hybrid materials are used to create sorbents of 3d-metal ions (Liu et al., 2002); to immobilize enzymes (Airoldi \& Monteiro, 2000); as a solid phase for the liquid chromatography of organic compounds (Budanova et al., 2001), including enantiomers (Senso et al., 1999); and to improve the mechanical properties of other polymers (Yeh et al., 2007). Other oxides in combination with chitosan allow us to obtain biosensors based on $\mathrm{ZnO}$ substrate (Khan et al., 2008), selective sorbents of fluoride ions based on $\mathrm{Al}_{2} \mathrm{O}_{3}$ substrate (Viswanathana \& Meenakshib, 2010) and magnetic materials based on $\mathrm{Fe}_{3} \mathrm{O}_{4}$ substrate ( $\mathrm{Li}$ et al., 2008). Using an organic polymer (e.g., cellulose) as a substrate also has advantages in the sorption of metal ions (Corma et al., 2007). Metal-containing hybrid organo-inorganic materials can also be used as antibacterial composites (Mei et al., 2009), as sorbents of proteins (Shi et al., 2003), and as pervaporation membranes (Varghese et al., 2010).

Nanostructured metal oxides, which are distinguished by extremely developed surface and porosity of particles, are new promising materials for different fields of science and technology, especially, for heterogeneous catalysis and chemistry of adsorption phenomena (Zakharova et al., 2005).

Many sorption and catalytic processes are $\mathrm{pH}$-dependent. Therefore, the determination of acidity and other acid-base characteristics in pores of inorganic, organo-inorganic materials is of great practical interest, since the catalytic and adsorption properties of solid-phase objects are affected by not only the chemical nature of solutions, but also specific conditions inside pores and on the surface of these materials. The mobility of liquid molecules in pores of inorganic sorbents was investigated by some authors using the spin probe method (Borbat et al., 1990; Martini et al., 1985 ). Recently, a new method was developed for the determination of medium acidity in pores of solids ( $\mathrm{pH}$ int) by means of $\mathrm{pH}$-sensitive nitroxide radicals (NRs) as spin probes (Molochnikov et al., 1996 ; Zamaraev et al., 1995). In recent years, this method was used to measure $\mathrm{pHint}$ in micropores of various cross-linked organic polyelectrolytes (ion-exchange resins and films) (Molochnikov et al., 1996, 2004) and in pores of some zeolites and kaolin (Zamaraev et al., 1995). We found that $\mathrm{pH}$ int inside sorbents differ from the $\mathrm{pH}$ of external solutions by 0.8-2.1 units (Molochnikov et al., 1996). The method developed allowed us to study the processes of sorption and hydrolysis in ionexchange resins and the catalytic properties of $\mathrm{Cu}^{2+}$ - containing carboxyl cation exchangers (Kovaleva et al., 2000), to determine ionization constants of functional groups and to give a critical estimation to the regularities previously found for the behavior of adsorbents in aqueous media. 
$\mathrm{pH}$-sensitive nitroxide radicals (NR) as labels were also used to determine surface electrical potential (SEP) of different biological objects like phospholipids (SLP) - derivatives of 1,2dipalmitoyl-sn-glycero-3-phosphothioethanol (PTE) (Voinov et al., 2009) and the mixed bilayers composed of dimyristoylphosphatidylglycerol and dimyristoylphosphatidilcholine (Khramtsov \& Weiner, 1988).

This work is aimed to review the applications of $\mathrm{pH}$-sensitive NR as probes and labels for determination of local acidic and electrochemical characteristics of inorganic and organoinorganic materials and systems such as :

- $\mathrm{Al}_{2} \mathrm{O}_{3}$ (non-modified and modified with $\mathrm{F}^{-}$and $\mathrm{SO}_{4}{ }^{2-}$ ions) and $\mathrm{TiO}_{2}$ as hydrogels and nanopowders doped with $\mathrm{Cu}(\mathrm{II})$ (Molochnikov et al., 2007) ;

- $\quad$ pure and $\mathrm{Cu}^{2+}$-containing solid-phase composites based on nanostructured $\mathrm{SiO}_{2}$ and $\mathrm{TiO}_{2}$ and powder cellulose (Shishmakov et al., 2010; Parshina et al., 2011) ;

- pure and $\mathrm{Co}^{2+}$-containing hybrid organo-inorganic materials based on the chitosan$\mathrm{SiO}_{2}$, chitosan- $\mathrm{Al}_{2} \mathrm{O}_{3}$, and -chitosan-cellulose systems (Mekhaev et al., 2011a, 2011b).

\section{Experimental}

\subsection{Objects of study}

$\alpha-\mathrm{Al}_{2} \mathrm{O}_{3}$ (basic aluminum oxide), $\gamma-\mathrm{Al}_{2} \mathrm{O}_{3}$ and its acid-modified ( $\mathrm{HF}$ and $\mathrm{H}_{2} \mathrm{SO}_{4}$ ) derivatives were supplied by A. M. Volodin. The IK-02-200 type $\gamma-\mathrm{Al}_{2} \mathrm{O}_{3}$ was synthesized by the calcination of aluminum hydroxide at $600^{\circ} \mathrm{C} . \gamma-\mathrm{Al}_{2} \mathrm{O}_{3}$ was modified through the sample impregnation with acids followed by calcination at $600^{\circ} \mathrm{C}$ that resulted in changes in the acidic properties of its surface (the phase composition and specific surface area of the samples remained unchanged). $\alpha-\mathrm{Al}_{2} \mathrm{O}_{3}$ was prepared by the long-term heating of $\gamma-\mathrm{Al}_{2} \mathrm{O}_{3}$ to $1300^{\circ} \mathrm{C}$. $\gamma-\mathbf{A l}_{2} \mathrm{O}_{3}$ and $\alpha-\mathbf{A l}_{2} \mathrm{O}_{3}$ had specific surface areas of 220 and $145 \mathrm{~m}^{2} / \mathrm{g}$, and an average pore diameter of $6 \mathrm{~nm}$, respectively. The structural characteristics of the matrices were determined from the isotherms of nitrogen adsorption at $77 \mathrm{~K}$ measured on a Micromeritics ASAP 1400 volumetric setup and by mercury porosimetry with a Micromeritics Pore Size 9300 setup in the Institute of Catalysis, Siberian Division, Russian Academy of Sciences.

The technique of synthesis of $\mathrm{TiO}_{2}$ hydrogel through the hydrolysis of a tetrabutyl titanate solution in methanol with water at room temperature and under intensive agitation is given in (Shishmakov et al., 2003). The precipitate was washed out with water until no butanol in washing water was observed and heated to $100^{\circ} \mathrm{C}$. The resulting product was $\mathrm{TiO}_{2}$ xerogel.

$\mathrm{SiO}_{2}$ hydrogel was synthesised by dissolving $10 \mathrm{ml}$ of $\mathrm{Na}_{2} \mathrm{SiO}_{3}$ (TU 6-15-433-92) in $30 \mathrm{ml}$ of $\mathrm{H}_{2} \mathrm{O}$. Then the hydrolysis of $\mathrm{Na}_{2} \mathrm{SiO}_{3}$ solution in $30 \mathrm{ml}$ of $10 \% \mathrm{HCl}$ solution was pursued under intensive agitation. During the reaction of condensation a gelatinous $\mathrm{SiO}_{2}$ gel and $\mathrm{NaCl}$ are formed. The precipitate was filtered off until no chlorine ions in washing water was observed, and dried at $100{ }^{\circ} \mathrm{C}$ during $24 \mathrm{~h}$ until it attained a constant weight. The resulting product was $\mathrm{SiO}_{2}$ xerogel. 
Powder cellulose (PC) was obtained by hydrolysis of cellulose sulfate (Baikal Cellulose plant, TU OP 13-02794 88-08-91) in $2.5 \mathrm{~N}$ hydrochloric acid at $100^{\circ} \mathrm{C}$. The hydrolysis was carried out for $2 \mathrm{~h}$. The resulting product was washed on a filter with distilled water to the neutral $\mathrm{pH}$ of the washing water and dried at $100^{\circ} \mathrm{C}$.

Composite materials (CMs) based on nanostructured $\mathrm{TiO}_{2}$ and $\mathrm{PC}$ called as $\mathrm{TiO}_{2}-\mathrm{PC}$ xerogels of 70, 53 and $43 \%$ wt. $\mathrm{TiO}_{2}$ were prepared by diluting $3 \mathrm{~g}$ of tetrabutoxytitanium and $0.5 ; 1$ and $1.5 \mathrm{~g}$ of $\mathrm{PC}$, respectively, in $3 \mathrm{~mL}$ of methanol. The hydrolysis was pursued in $10 \mathrm{~mL}$ of water at $20^{\circ} \mathrm{C}$ under intensive agitation, resulting in the condension of $\mathrm{TiO}_{2}$ ( $\mathrm{PC}$ didn't participate in condensation). $\mathrm{The}^{\mathrm{TiO}_{2}}$ particles formed were deposited on a surface of PC.

Composite materials (CMs) based on nanostructured $\mathrm{SiO}_{2}$ and $\mathrm{PC}$ called as $\mathrm{SiO}_{2}-\mathrm{PC}$ xerogels of 68,52 and $35 \%$ wt. were prepared .from the solutions of $10 ; 5 ; 5 \mathrm{ml}$ of $\mathrm{Na}_{2} \mathrm{SiO}_{3}$ and $30 ; 15 ; 15 \mathrm{ml}$ of $\mathrm{H}_{2} \mathrm{O}$ which were modified by introducing $2 ; 2 ; 4 \mathrm{~g}$ of PC, respectively. The hydrolysis of the first solution were peformed in $30 \mathrm{~mL}$ of $10 \% \mathrm{HCL}$, and that of other ones was done in $15 \mathrm{~mL}$ of $10 \%$ HCL.

The precipitates of the CMs prepared were washed out with hot water, filtered and dried at $100{ }^{\circ} \mathrm{C}$ during $24 \mathrm{~h}$ until they attained a constant weight.

The specific surface $\left(\mathrm{S}_{\mathrm{sp}}\right)$ of the synthesized samples was measured using a SORBIMS instrument (ZAO Meta, Novosibirsk) and calculated by the BET procedure. The data are given in Table 1 (Parshina et al., 2011).

\begin{tabular}{|c|c|c|c|c|c|c|c|}
\hline & \multicolumn{4}{|c|}{$\mathrm{TiO}_{2}$} & \multicolumn{3}{c|}{$\mathrm{SiO}_{2}$} \\
\hline $\mathbf{P C}, \%$ & 0 & 30 & 47 & 57 & 0 & 32 & 65 \\
\hline $\mathbf{S}_{\text {sp }}, \mathbf{m}^{2} / \mathbf{g}$ & 66 & 177 & 226.4 & 261.9 & 29.5 & 145 & 239 \\
\hline
\end{tabular}

Table 1. The specific surface of the pure xerogels of $\mathrm{TiO}_{2}$ and $\mathrm{SiO}_{2}$ and the composites with different percentage of PC

Since the specific surface of powder cellulose did not exceed $1 \mathrm{~m}^{2} / \mathrm{g}$, the growth of $\mathrm{S}_{\mathrm{sp}}$ was caused by the fragmentation of $\mathrm{TiO}_{2}$ and $\mathrm{SiO}_{2}$ particles deposited on the PC surface during the synthesis of CMs. According to the absolute values of $S_{s p}$, the procedure used for the preparation of CMs afforded dioxides with a high degree of dispersity.

Powdered samples nanostructured $\mathrm{TiO}_{2}$ were prepared through heating a sol for $1 \mathrm{~h}$ at $200^{\circ} \mathrm{C}$ followed by washing with distilled water to remove residual acid used for the sol stabilization and drying at room temperature. The specific surface area of the samples was $240 \mathrm{~m}^{2} / \mathrm{g}$, and the average particle diameter ranged from 4 to $5 \mathrm{~nm}$ (Poznyak et al., 1999).

Microcrystalline cellulose (MCC) with an ash content of $0.16 \%$ and a humidity of $1.1 \%$ produced by JSC Polyex; Basic aluminum oxide; BS-50 silica and chitosan produced by JSC Sonat (Moscow) were used to obtain chitosan-containing ahybride organo-inorganic systems. The degree of deacetylation of chitosan (DD) determined by $1 \mathrm{H}$ NMR spectroscopy, its molecular weght as determined by viscosimetry and the ash content were found to be $0.84,250$ $\mathrm{kDa}$ and $0.19 \%$, respectively (Mechaev et al., 2011a). The BS-50 type silica had a specific surface area of $45 \mathrm{~m}^{2} / \mathrm{g}$ and an average diameter of pores of $15 \mathrm{~nm}$ (Mekhaev et al., 2011a). 
The hybrid chitosan- $\left(\mathrm{SiO}_{2}, \mathrm{Al}_{2} \mathrm{O}_{3}\right.$, cellulose $)$ systems were obtained by depositing chitosan on the support surface.

$0.3 \mathrm{~g}$ (1.8 mmol) of citosan was dissolved in $14.5 \mathrm{ml}$ of water containing $0.22 \mathrm{ml}(3.84 \mathrm{mmol})$ of acetic acid with constant stirring. The substrate in quantities of $3 \mathrm{~g}$ was then added, and the solution was stirred for 30 min more.

$1 \mathrm{M} \mathrm{NaOH}$ solution was added to the suspension under stirring until the $\mathrm{pH}$ value reached 13. The precipitate was filtered, washed until the $\mathrm{pH}$ value was 7 , and dried at $60^{\circ} \mathrm{C}$ until it attained a constant weight.

$\mathrm{CHN}$ analysis was performed using an automatic analyzer PerkinElmer, Inc. The data are given in Table 1. IR spectra of diffuse reflection were recorded using the PerkinElmer Spectrum One spectrometer.

\begin{tabular}{|c|c|c|c|c|c|c|}
\hline System & $\mathrm{C}$ & $\mathbf{H}$ & $\mathbf{N}$ & $\mathrm{Cl}$ & Co & Formula \\
\hline MCC-Chitosan & \begin{tabular}{|c|}
43.08 \\
$(43.11)$
\end{tabular} & $\begin{array}{c}6.42 \\
(6.35)\end{array}$ & $\begin{array}{c}0.37 \\
(0.39)\end{array}$ & - & - & $10 \mathrm{C}_{6} \mathrm{H}_{10} \mathrm{O}_{5} \cdot 0.5 \mathrm{C}_{6} \mathrm{H}_{11} \mathrm{NO}_{4} \cdot 3 \mathrm{H}_{2} \mathrm{O}$ \\
\hline $\mathrm{Al}_{2} \mathrm{O}_{3}-$ Chitosan & \begin{tabular}{|c|}
4.07 \\
$(4.01)$ \\
\end{tabular} & \begin{tabular}{|c|}
1.04 \\
$(0.61)$ \\
\end{tabular} & $\begin{array}{c}0.46 \\
(0.78) \\
\end{array}$ & - & - & $16 \mathrm{Al}_{2} \mathrm{O}_{3} \cdot \mathrm{C}_{6} \mathrm{H}_{11} \mathrm{NO}_{4}$ \\
\hline $\mathrm{SiO}_{2}-$ Chitosan & \begin{tabular}{|c|}
4.50 \\
$(4.49)$
\end{tabular} & $\begin{array}{c}0.94 \\
(0.68)\end{array}$ & $\begin{array}{c}0.51 \\
(0.87)\end{array}$ & - & - & $24 \mathrm{SiO}_{2} \cdot \mathrm{C}_{6} \mathrm{H}_{11} \mathrm{NO}_{4}$ \\
\hline $\begin{array}{l}\text { MCC-Chitosan- } \\
\mathrm{Co}^{2+}(\mathrm{I})\end{array}$ & $\begin{array}{c}43.12 \\
(43.12)\end{array}$ & $\begin{array}{c}6.15 \\
(6.04)\end{array}$ & $\begin{array}{c}0.59 \\
(0.40)\end{array}$ & $\begin{array}{c}1.30 \\
(1.28)\end{array}$ & $\begin{array}{c}1.38 \\
(1.33)\end{array}$ & $\begin{array}{c}10 \mathrm{C}_{6} \mathrm{H}_{10} \mathrm{O}_{5} \cdot 0.5 \mathrm{C}_{6} \mathrm{H}_{11} \mathrm{NO}_{4} \\
\cdot \mathrm{Co} 0.4(\mathrm{OH})_{0.17} \mathrm{Cl}_{0.65}\end{array}$ \\
\hline $\begin{array}{c}\mathrm{Al}_{2} \mathrm{O}_{3}-\mathrm{Chitosan} \\
\mathrm{Co}^{2+}(\mathrm{II}) \\
\end{array}$ & \begin{tabular}{|c|}
3.64 \\
$(3.82)$ \\
\end{tabular} & \begin{tabular}{|c|}
0.79 \\
$(0.58)$ \\
\end{tabular} & $\begin{array}{c}0.47 \\
(0.74) \\
\end{array}$ & $\begin{array}{c}2.69 \\
(2.63) \\
\end{array}$ & $\begin{array}{c}2.18 \\
(2.19) \\
\end{array}$ & $16 \mathrm{Al}_{2} \mathrm{O}_{3} \cdot \mathrm{C}_{6} \mathrm{H}_{11} \mathrm{NO}_{4} \cdot 0.7 \mathrm{CoCl}_{2}$ \\
\hline $\begin{array}{l}\mathrm{SiO}_{2}-\mathrm{Chitosan}^{-} \\
\mathrm{Co}^{2+}(\mathrm{III})\end{array}$ & \begin{tabular}{|c|}
4.02 \\
$(4.26)$
\end{tabular} & $\begin{array}{c}0.89 \\
(0.65)\end{array}$ & $\begin{array}{c}0.58 \\
(0.82)\end{array}$ & $\begin{array}{c}2.03 \\
(2.02)\end{array}$ & $\begin{array}{c}3.07 \\
(3.07)\end{array}$ & $16 \mathrm{SiO}_{2} \cdot \mathrm{C}_{6} \mathrm{H}_{11} \mathrm{NO}_{4} \cdot \mathrm{Co}_{0.88} \mathrm{Cl}_{0.96}$ \\
\hline
\end{tabular}

Table 2. Composition (\%) of hybrid systems (calculated values are shown in brackets )

The surface area of the samples was determined by nitrogen adsorption in accordance with the BET method using a TriStar 3000 V.6.03A instrument. The instrumental error was $0.1 \mathrm{~m}^{2} / \mathrm{g}$. The size of particles was estimated under the assumption that the particles were spherical.

The surface area $\left(\mathrm{S}_{\mathrm{sp}}\right)$ and the diameter of particles (D) were found to be $28.9 \mathrm{~m}^{2} / \mathrm{g}$ and 47 $\mathrm{nm} ; 123.9 \mathrm{~m} / \mathrm{g}$ and $7 \mathrm{~nm} ; 2.4 \mathrm{~m}^{2} / \mathrm{g}$ and $818 \mathrm{~nm}$ for chitosan- $\mathrm{SiO}_{2}$, chitosan- $\mathrm{Al}_{2} \mathrm{O}_{3}$ and chitosan-MCC hybride systems, respectively.

\subsection{Saturation of samples with $\mathrm{Cu}^{2+}$ and $\mathrm{Co}^{2+}$ ions}

\subsubsection{Saturation of samples with $\mathrm{Cu}^{2+}$ Ions}

A $0.1 \mathrm{M} \mathrm{NaNO} 3$ solution $(10 \mathrm{ml})$ was added into weighed samlpes (200 mg) of nanostructured $\mathrm{TiO}_{2}$, and the samples were kept for one week at a constant solution $\mathrm{pH}$ (5.5) held by adding dilute $\mathrm{NaOH}$ and $\mathrm{HNO}_{3}$ solutions. The sorption of $\mathrm{Cu}^{2+}$ ions on nanostructured $\mathrm{TiO}_{2}$ was performed by exposing samples in $\mathrm{Cu}\left(\mathrm{NO}_{3}\right)_{2}$ solutions $(10 \mathrm{ml})$ 
with concentrations of $10^{-4}, 10^{-3}$, and $10^{-2} \mathrm{~mol} / \mathrm{L}$ and ionic strength $(\mu)$ of 0.1 , which was adjusted using $\mathrm{NaNO}_{3}$. Solution $\mathrm{pH}$ equal to 4.3 was maintained by the titration with small volumes of $\mathrm{NaOH}$ and $\mathrm{HNO}_{3}$ solutions. After the equilibrium was established, the residual amount of $\mathrm{Cu}^{2+}$ ions the equilibrium solutions was measured to determine the amount of sorbed $\mathrm{Cu}^{2+}$. Then, $\mathrm{TiO}_{2}$ was separated from the solutions by centrifugation. The samples were washed twice with a $0.1 \mathrm{M} \mathrm{NaNO}_{3}$ solution $(\mathrm{pH} 4.3)$ to remove adsorbed $\mathrm{Cu}^{2+}$-ions.

$\mathrm{Cu}^{2+}$ ions were sorbed on $\mathrm{TiO}_{2}$ hydrogel from $\mathrm{CuCl}_{2}$ and $\mathrm{Cu}\left(\mathrm{NO}_{3}\right)_{2}$ with subsequent its removal by filtration and drying at $20^{\circ} \mathrm{C}$ for 3 days upto constant weights of the precipitates. A volume of solution and a mass of hydrogel were changed to vary the content of $\mathrm{Cu}^{2+}$ ions in the phase of the studied $\mathrm{TiO}_{2}$ hydrogel, which was determined by the atomic absorption method on a Perkin Elmer 403 spectrometer. As the ESR spectra of $\mathrm{Cu}^{2+}$-containing hydrated gels are difficult to record, hydrogel samples filtered and dried at room temperature were used. Preliminary experiments were performed to select the sample drying conditions preventing the structural changes of the complexes formed.

$\mathrm{Cu}^{2+}$ - containing composites based nanostructured $\mathrm{SiO}_{2}, \mathrm{TiO}_{2}$, and cellulose powder were prepared by sorption of $\mathrm{Cu}^{2+}$ ions on a hydrogel from an aqueous solution of $\mathrm{CuCl}_{2} \bullet 2 \mathrm{H}_{2} \mathrm{O}$. The volumes of hydrogels of the samples studied were calculated from the masses of xerogels obtained by hydrogels drying. For preparation of $\mathrm{Cu}^{2+}$-containing $\mathrm{TiO}_{2}$ and $\mathrm{SiO}_{2}$ xerogels and the related CMs, a $0.01 \mathrm{~g} \mathrm{CuCl}_{2} \bullet 2 \mathrm{H}_{2} \mathrm{O}$ containing $0.059 \mathrm{mmol}$ of $\mathrm{Cu}^{2+}$ ions and $2 \mathrm{ml}$ of $\mathrm{H}_{2} \mathrm{O}$ and the calculated volumes of hydrogels prepared were added into flasks. The samples were kept in the contact with a $\mathrm{Cu}^{2+}$-containing solution about $24 \mathrm{~h}$ upto the equilibrium was established. Then, the residual amounts of $\mathrm{Cu}^{2+}$ ions in the equilibrium solutions was measured to determine the amount of sorbed $\mathrm{Cu}^{2+}$ ions. The initial and residual amounts of $\mathrm{Cu}^{2+}$-ions in a solution were measured using colorimeter KFK-2MP.

\subsubsection{Synthesis and characterization of the Cobalt-Containing Chitosan hybrid systems}

Cobalt-Containing Chitosan-Supported Systems were synthesised through stirring a mixture containing $0.24 \mathrm{~g}$ of $\mathrm{CoCl}_{2} \bullet 6 \mathrm{H}_{2} \mathrm{O}, 2 \mathrm{~g}$ of chitosan-supported hybrid system and 20 $\mathrm{ml}$ of ethanol under reflux condenser for $24 \mathrm{~h}$. The obtained cake was filtered off, rinsed with ethanol $(15 \mathrm{ml} \times 3$ times $)$ and dried at room temperature until the weight became constant. The elemental compositions of the hybrid system surfaces were determined using an analytical setup based on a VEGA II LMH scanning electron microscope and an INCA ENERGY energy dispersive microanalysis system (Mekhaev et al., 2011a, 2011b). The data are shown in Table 2.

\section{3. $\mathrm{pH}$ probes}

The $\mathrm{pH}$ values of solutions inside pores and near the surface of the studied inorganic and organo-inorganic materials were determined using spin probes, namely, $\mathrm{pH}$-sensitive NRs of the imidazoline (R1, R2) and imidazolidine (R3) types (Table 3), which were synthesized at the Novosibirsk Institute of Organic Chemistry, Siberian Branch, Russian Academy of Sciences (Volodarskii et al., 1988; Khramtsov et al., 1998; Kirilyuk et al., 2005). 


\subsection{Recording and processing of the ESR spectra of NR}

The ESR spectra were recorded on a PS 100.X ESR spectrometer (ADANI, Belarus) in a three-centimeter $(X)$ wavelength range at room temperature. Quartz sample holders with an internal diameter of $3.5 \mathrm{~mm}$ were used for solid samples. Solution spectra were recorded using quartz capillaries.

Figure 1 shows characteristic ESR spectra of the pH-sensitive NR in aqueous solutions. According to the ESR theory, isotropic signals are induced by the fast-motioned NR molecules (correlation times of $10^{-10} \mathrm{~s}$ and less) and present the triplet of fine lines. Depending on solution $\mathrm{pH}, \mathrm{NR}$ can be in protonated $\left(\mathrm{RH}^{+}\right)$, deprotonated $(\mathrm{R})$, or intermediate (mixed) forms. Because hyperfine splitting constants an for $\mathrm{RH}^{+}$and $\mathrm{R}$ forms of the radicals are different (Table 3), in their ESR spectra, the distance $\boldsymbol{a}$ between the low and central-field component of the triplet increases gradually with $\mathrm{pH}$ of a solution, from the values characteristic of the $\mathrm{RH}^{+}$form to those typical of the $\mathrm{R}$ form (Fig. 1). This characteristic is a superposition of hyperfine splitting constants (an) characterizing protonated and deprotonated forms of the nitroxide radical. From the results of measuring $a$ values during titration, the calibration curves reflecting the dependences $a$ vs. $\mathrm{pH}$ were plotted for each NR used (for example, see Fig. 2, 3 curve 1). In order to plot the calibration curves, NR solutions $\left(10^{-4} \mathrm{~mol} / \mathrm{l} ; \mu=0.1\right)$ were titrated either with dilute $\mathrm{HCl}$ and $\mathrm{KOH}$ solutions (used for all the samples, excepting hybride systems)( Molochnikov et al.,2007; Parshina et al., 2011 ; Shishmakov et al., 2010) or citrate-phoshate (pH 3.5-7.8) and citrate-salt ( $\mathrm{pH}$ 1.6-4.8) buffer solutions (used for hybride systems) (Mekhaev et al., 2011a, 2011b). to vary the $\mathrm{pH}$ within the range of NR sensitivity of $2.5-7.5$.

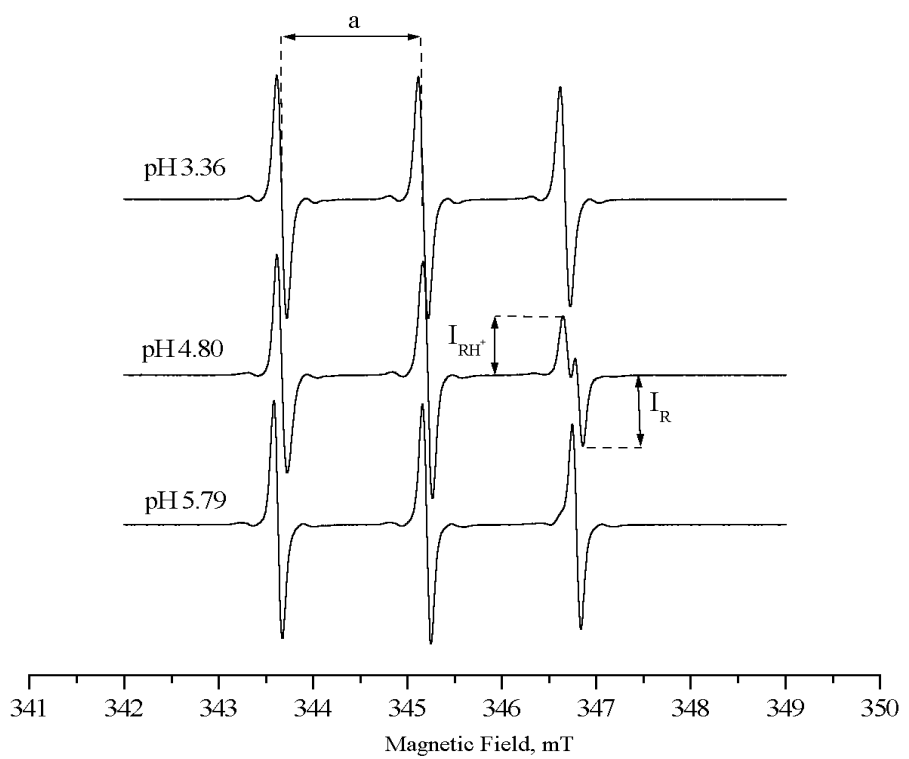

Figure 1. The ESR spectra of the aqueous solution of NR R3 at different $\mathrm{pH}$ in the $\mathrm{X}$ range of wavelengths at $293 \mathrm{~K}$. IRH $\mathrm{IH}^{+}$and $\mathrm{I}$ are the intensities of ESR peaks for $\mathrm{RH}^{+}$and $\mathrm{R}$ forms of the radical, respectively 


\begin{tabular}{|c|c|c|c|c|c|}
\hline \multirow[t]{2}{*}{ Radical } & \multirow{2}{*}{$\begin{array}{c}\mathrm{pK}_{\mathrm{a}} \\
( \pm 0.1)\end{array}$} & \multicolumn{2}{|c|}{$\begin{array}{l}\text { g-factor } \\
( \pm 0.0001)\end{array}$} & \multicolumn{2}{|c|}{$\begin{array}{c}\text { aN } \\
( \pm 0.006 \mathrm{mT})\end{array}$} \\
\hline & & $\mathrm{R}$ & $\mathrm{RH}^{+}$ & $\mathrm{R}$ & $\mathrm{RH}^{+}$ \\
\hline${ }^{\mathrm{R} 1}$ & $\begin{array}{l}3.15 \\
4.89\end{array}$ & 2.0048 & 2.0051 & 更 & 1.390 \\
\hline${ }^{\mathrm{R} 2} \mathrm{H}$ & 3.55 & 2.0048 & 2.0051 & 1.590 & 1.515 \\
\hline $\mathrm{R} 3$ & 4.70 & 2.0048 & 2.0051 & 1.590 & 1.485 \\
\hline
\end{tabular}

Table 3. ESR paramters and $\mathrm{pK} a$ values of nitroxide radicals used 


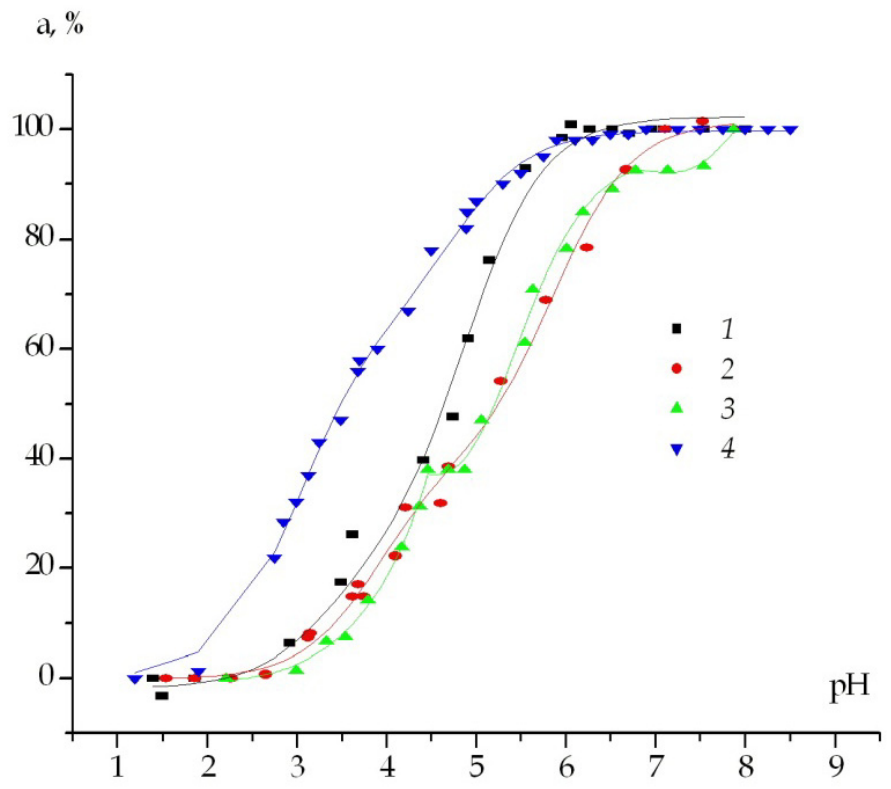

Figure 2. Titration curves for NR R1 in bulk aqueous solution (calibration curve) (1), $\alpha-\mathrm{Al}_{2} \mathrm{O}_{3}(2)$, the $\mathrm{BS}-50 \mathrm{SiO}_{2}(3)$ and $\gamma-\mathrm{Al}_{2} \mathrm{O}_{3}(4)$. a, $\%=\left(\left(\mathrm{a}-\mathrm{anRH}^{+}\right) /\left(\mathrm{anR}-\mathrm{anRH}^{+}\right)\right) \times 100 \%$

\subsection{Determination of $\mathrm{pH}$ in the pore and near the sample surface using $\mathrm{pH}-$ sensitive spin probes}

An aqueous $\mathrm{KCl}$ solution $(10 \mathrm{ml})$ with an ionic strength of 0.1 was added to an oxide sample (200 mg) and the mixture was allowed to stand for a preset time. Then, the solution was thoroughly decanted and an NR solution $\left(10^{-4} \mathrm{~mol} / \mathrm{L}, \mu=0.1\right)$ was added to the sample. In some cases, required initial $\mathrm{pH}$ values of radical solution were obtained by preliminary mixing of $\mathrm{HCl}$ and $\mathrm{KOH}$ solutions. After the equilibrium was established, the suspension was titrated with $\mathrm{HCl}$ and $\mathrm{KOH}\left(\mathrm{HNO}_{3}\right.$ and $\left.\mathrm{NaOH}\right)$ solutions to plot the titration curve for the NR present in the sample.

For chitosan cobalt-containing hybrid systems and solid-phase composites based on $\mathrm{SiO}_{2}$, $\mathrm{TiO}_{2}$ and cellulose powder the method of multiply batches was used: $0.05 \mathrm{~g}$ of sample was kept in $5 \mathrm{ml}$ of buffer aqueous solution containing nitroxide radicals for 2 days (established experimentally). The solution was then decanted. 
The $\mathrm{pH}$ values of the equilibrium solutions ( $\mathrm{pH}$ ext) over the samples were measured using a Mettler Toledo $\mathrm{pH}$ meter (Switzerland) with an accuracy of 0.01 units. The samples separated from the solutions by centrifugation or filtration were placed into unsealed quartz ampules and their ESR spectra were recorded. After measuring the $a$ distances in the ESR spectra of corresponding radicals located in the samples (Fig. 4), the pHint values of the studied materials were determined using the calibration curves (Fig. 2,3).

$a_{,} \%$

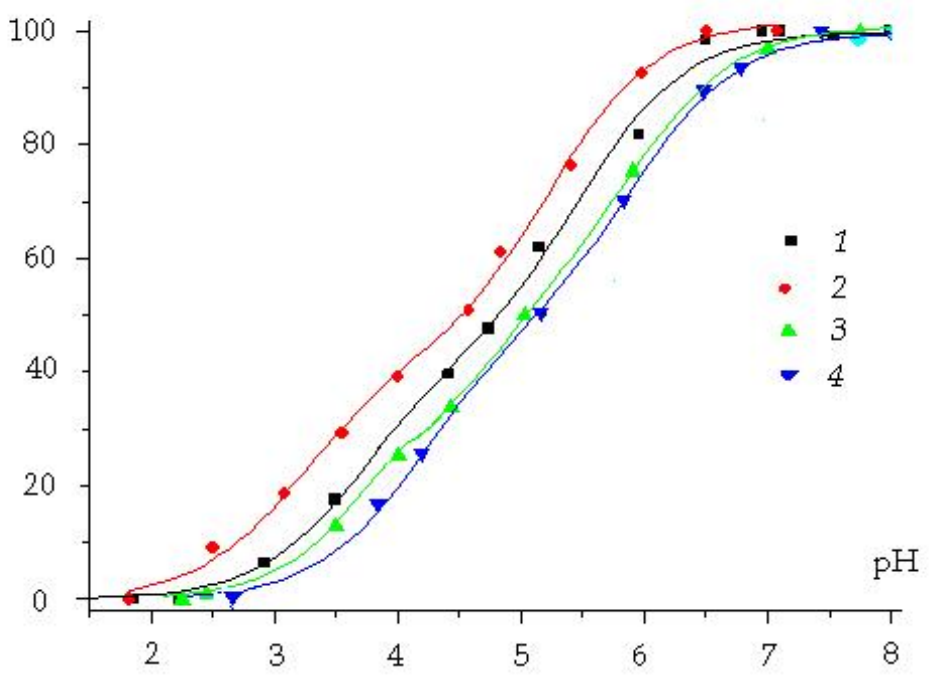

Figure 3. Titration curves for NR R1 in bulk aqueous solution (calibration curve) (1), $\mathrm{PC}(2), \mathrm{SiO}_{2}$ (3) and $\mathrm{TiO}_{2}(4)$ xerogels. a, $\%=((\mathrm{a}-\mathrm{aNRH}+) /(\mathrm{aNR}-\mathrm{aNRH}+)) \times 100 \%$

As can be seen from Fig. 4, the ESR spectra of NR in the samples studied represent the superpositions of three components of an isotropic signal of the probes in aqueous solutions inside pores and a spectrum of the probes immobilized on the surface of the objects studied. For determination of $\mathrm{pHint}$ values, only the isotropic signals in the ESR spectra were used. 


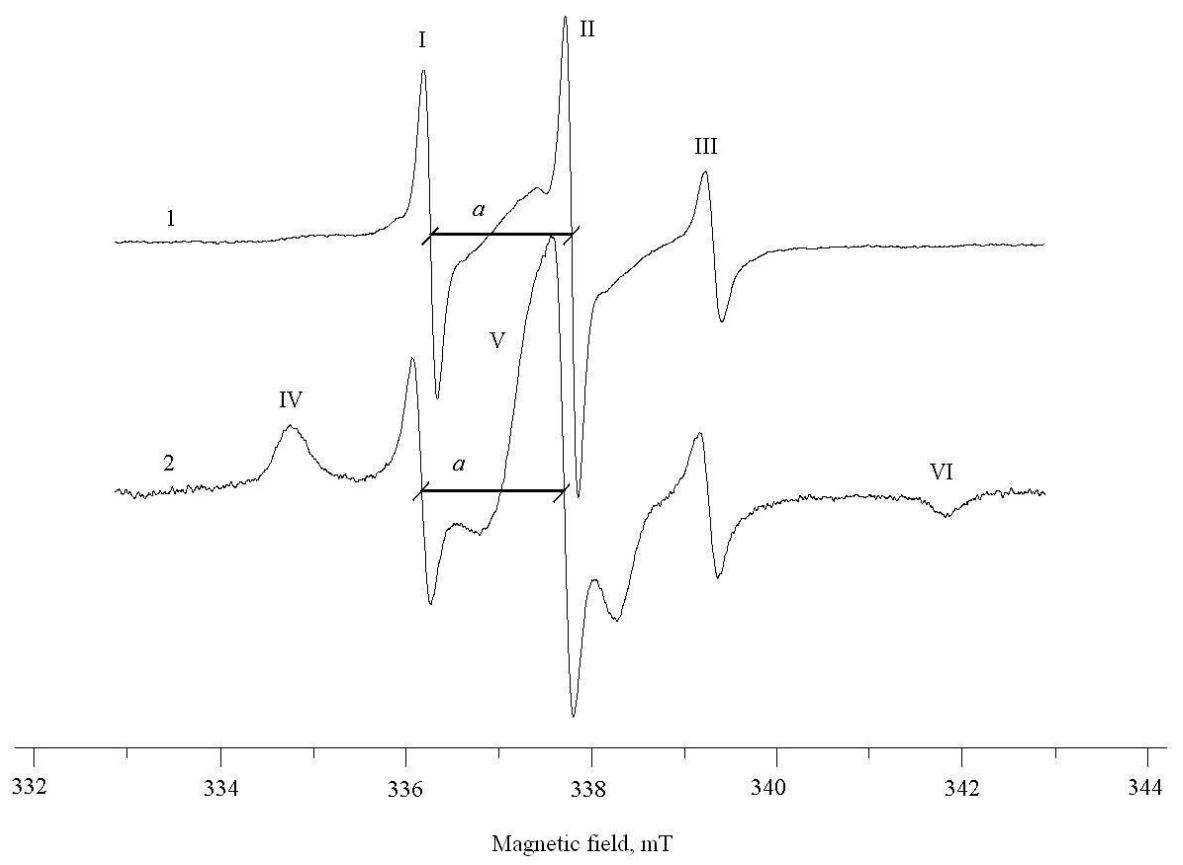

I, II,II - components of an isotropic spectrum ; IV, V, VI - components of the spectrum of the immobilized probes

Figure 4. The ESR spectra of NR R1 in the samples of $\mathrm{CMs} \mathrm{SiO}_{2}-\mathrm{PC}(68 \%$ wt.SiO 2$)$ at $\mathrm{pH} 7.8$ (1) and $\mathrm{pH}$ $3.7(2)$

3. Results and discussion. Acid-base equilibria of inorganic and organoinorganic materials and systems

\subsection{Inorganic oxide materials}

\subsubsection{Pure oxides}

The comparison of the titration curves for NR R1 radical in $\gamma-\mathrm{Al}_{2} \mathrm{O}_{3}, \alpha-\mathrm{Al}_{2} \mathrm{O}_{3}$, the BS-50 type $\mathrm{SiO}_{2}$ and $\mathrm{TiO}_{2}$ and $\mathrm{SiO}_{2}$ xerogels with the calibration curve of this NR (Fig. 2, 3) indicates that for $\gamma-\mathrm{Al}_{2} \mathrm{O}_{3}$, the curve is shifted to the left, and for other samples, to the right. As was shown previously for organic sorbents (Molochnikov et al., 2004), the left- side shift of the titration curves for the NRs used is characteristic of anionites in acidic solutions in the $\mathrm{pH}$ range, where amino groups bind hydrogen ions, for example,

$$
\mathrm{P}-\mathrm{NH}_{2}+\mathrm{H}^{+} \leftrightarrows{\mathrm{P}-\mathrm{NH}_{3}}^{+}
$$


where $P$ is the sorbent matrix. At the same time, the shift in the titration curves to the right is related to the dissociation of acidic functional groups of cationites, for example, a carboxylic one,

$$
\mathrm{P}-\mathrm{COOH} \leftrightarrows \mathrm{P}-\mathrm{COO}^{-}+\mathrm{H}^{+}
$$

Thus, the shift of the titration curve of $\mathrm{R} 1$ to the left observed for $\gamma-\mathrm{Al}_{2} \mathrm{O}_{3}$ indicates the binding of $\mathrm{H}^{+}$ions with the surface ( $\mathrm{pH}$ intr is higher than solution $\mathrm{pH}$ ) and to a positive charge of $\gamma-\mathrm{Al}_{2} \mathrm{O}_{3}$ surface, while the right-hand side shift of the titration curve of this NR in $\mathrm{SiO}_{2}$ gel suggests the release of $\mathrm{H}^{+}$ions and, consequently, a negative surface charge.

According to the data reported in (Hubbard, 2002) the acidic dissociation of hydrated aluminum oxide occurs in two stages, which can be described by the following equations:

$$
\begin{gathered}
-\mathrm{AlOH}_{2}^{+}+\mathrm{H}_{2} \mathrm{O} \leftrightarrows-\mathrm{AlOH}+\mathrm{H}_{3} \mathrm{O}^{+} \\
-\mathrm{AlOH}+\mathrm{H}_{2} \mathrm{O} \leftrightarrows-\mathrm{AlO}^{-}+\mathrm{H}_{3} \mathrm{O}^{+}
\end{gathered}
$$

The $\mathrm{pK}$ avalues of these equilibria ( $\mathrm{pK}_{\mathrm{a} 1}=5.87$ and $\mathrm{pK}_{\mathrm{a} 2}=7.50$ ) are given in (Lidin et al., 1987). Using NR, we can determine only $\mathrm{pH}$ values relevant to the ascending part of its S-shaped calibration curve (Fig. 2, 3 curve 1), i.e., the range, in which variations in a parameter correspond to variations in $\mathrm{pH}$. The range of $\mathrm{pH}$ values appropriate to the ascending part of the calibration curve for a given NR is referred to as the zone of its sensitivity. The sensitivity zone of NR R1 falls in the $\mathrm{pH}$ range from 2.5 to 6.5 (Fig. 2, 3). If the above data on $\mathrm{pK}$ a reflect (even if qualitatively) the $\mathrm{pK}$ a of functional group dissociation for $\gamma-\mathrm{Al}_{2} \mathrm{O}_{3}$ studied, then the comparison of the sensitivity zone of NR R1 with pKa values indicates that the use of NR allows one to study only the $\mathrm{pH}$ range in which $\gamma-\mathrm{Al}_{2} \mathrm{O}_{3}$ either has a positive charge or is electrically neutral. On the other hand, there are data on the point of zero charge (PZC) for $\mathrm{Al}_{2} \mathrm{O}_{3}$ in the literature.

For example, as was shown previously, the $\mathrm{PZC}$ of an $\mathrm{Al}_{2} \mathrm{O}_{3}$ sample kept in water for a long time was equal to 9.2, and for $\mathrm{Al}_{2} \mathrm{O}_{3}$ treated at $1400^{\circ} \mathrm{C}$, the PZC decreased to 6.7 (Robinson et al., 1964). The first value corresponds to $\gamma-\mathrm{Al}_{2} \mathrm{O}_{3}$, and the second one, to $\alpha-\mathrm{Al}_{2} \mathrm{O}_{3}$. For hydrated $\mathrm{Al}_{2} \mathrm{O}_{3}$ the PZC was found to be equal to 8 , and it decreases as a result of the modification of $\mathrm{Al}_{2} \mathrm{O}_{3}$ surface with alkyl phosphate-based surfactants (Jeon et al., 1996). Moreover, these data suggest that, in the studied $\mathrm{pH}$ range, the surface of $\gamma-\mathrm{Al}_{2} \mathrm{O}_{3}$ has a positive charge that is in accordance with the shift of its titration curve to the left.

The $\mathrm{pH}$ int of the sorbents differ from the $\mathrm{pH}_{\text {ext }}$ by $0.5-1.5$ units (Table 3). Smaller $\mathrm{pH}$ intr values compared to $\mathrm{pH}$ of the external solutions for all the studied samples (except for $\gamma-\mathrm{Al}_{2} \mathrm{O}_{3}$ ) are indicative of the shift in titration curves of NR R1 to the right relative to the calibration curve, similarly to that demonstrated in Fig. 2, 3 all the samples excepting $\gamma-\mathrm{Al}_{2} \mathrm{O}_{3}$.

It should be noted that the $\mathrm{pH}$ int value determined in this study for the hydrated $\alpha-\mathrm{Al}_{2} \mathrm{O}_{3}$ is in good agreement with the PZC value found in (Robinson et al., 1964). From the data given in Table 3 we notice that in all the studied samples excepting $\gamma-\mathrm{Al}_{2} \mathrm{O}_{3}$ acidic centers 
predominate. However, the acidity of these centers is rather weak; their $\mathrm{pK}$ a of dissociation are presumably close to 6 . Only when strongly acidic sulfate residues appear in $\mathrm{Al}_{2} \mathrm{O}_{3}$, a drastic decrease in $\mathrm{pH}_{\text {int }}$ is observed as a result of their dissociation. It should be noted that the same decrease in $\mathrm{pH}_{\text {int }}$ of $\mathrm{TiO}_{2}$ hydrogel results from the sorption of $\mathrm{Cu}^{2+}$ ions by the hydrogel, which leads to the ion-exchange displacement of $\mathrm{H}^{+}$ions (Fig. 5).

\begin{tabular}{|c|c|c|}
\hline Sample & $\mathbf{p H e x t} \mathbf{( \pm 0 . 0 1 )}$ & $\mathbf{p H}$ int $( \pm \mathbf{0 . 1})$ \\
\hline$\alpha-\mathrm{Al}_{2} \mathrm{O}_{3}$ & 7.72 & 6.6 \\
\hline $\mathrm{Al}_{2} \mathrm{O}_{3}-\mathrm{F}^{-}$ & 6.9 & 6.4 \\
\hline $\mathrm{Al}_{2} \mathrm{O}_{3}-\mathrm{SO}_{4}{ }^{2-}$ & 4.9 & 3.8 \\
\hline$\gamma-\mathrm{Al}_{2} \mathrm{O}_{3}$ & 7.16 & $>7.3$ \\
\hline $\mathrm{TiO}_{2}$-hydrogel & 7.0 & 5.5 \\
\hline $\mathrm{BS}_{50}$ type $\mathrm{SiO}_{2}$ & 7.5 & 5.7 \\
\hline $\mathrm{TiO}_{2}$-xerogel & 7.0 & 6.1 \\
\hline $\mathrm{SiO}_{2}$-xerogel & 7.0 & 6.3 \\
\hline
\end{tabular}

Table 4. $\mathrm{pH}$ values of the external bulk solution of NR R1 and in the pores and near a surface of the inorganic materials studied

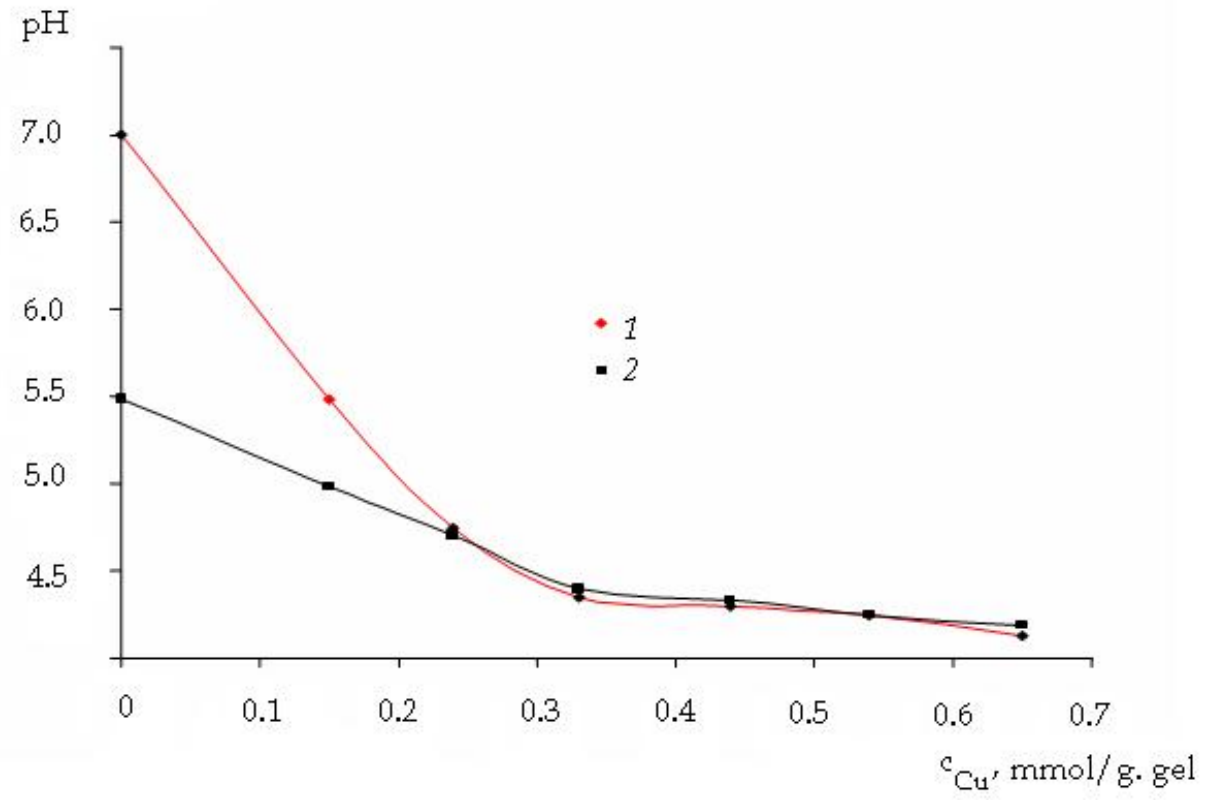

Figure 5. The $\mathrm{pH}$ values of a $\mathrm{CuCl}_{2}$ equilibrium solution ( $\mathrm{pHext}$ ) (1) and a solution inside $\mathrm{TiO}_{2}$ hydrogel ( $\mathrm{pH}$ int) (2) vs. the amount of sorbed $\mathrm{Cu}^{2+}(\mathrm{ccu})$

The titration curves of radicals occurring in organic sorbents are characterized by the presence of horizontal plateaus corresponding to constant $\mathrm{pHint}$ (parameter a remains unchanged), when the $\mathrm{pH}$ of the external solution increases (Molochnikov et al., 2004). The 
presence of the horizontal plateaus on the titration curves is related to the consumption of the titrant solution for the neutralization of functional groups of ionites. There was found no horizontal plateau on the titration curve of NR R1 in $\gamma-\mathrm{Al}_{2} \mathrm{O}_{3}$ within its zone of sensitivity (Fig.2). This fact can be explained either by the presence of a small number of acidic functional groups in $\gamma-\mathrm{Al}_{2} \mathrm{O}_{3}$ or by noncoincidence of $\mathrm{pK}$ a values of these acid groups with the zone of sensitivity of the radical used. Based on our experimental data, it is difficult to make a conclusion in favor of any of these assumptions.

It should be noted that the titration curve of NR R1 in the BS- $50 \mathrm{SiO}_{2}$ contains two horizontal plateaus corresponding two constant $\mathrm{pH}$ int determined near the $\mathrm{SiO}_{2}$ surface when the $\mathrm{pH}$ of the external solution is changed ( $\mathrm{pH}_{\mathrm{ext}}$ ) (Fig.2, curve 3). These plateaus are referred to as the titration process of functional groups on the surface (Golovkina et al., 2008). The pKa values for these groups were determined from the titration curves, and were $\mathrm{pK}_{\mathrm{a} 1}=4.4-4.7$ and $\mathrm{pK}_{\mathrm{a} 2}=6.5-6.8$. According to (Long et al., 1999; Zhao et al., 1997, 1998) amorphous $\mathrm{SiO}_{2}$ contains groups of three types: silanol, silandiol, and siloxane groups in a ratio of 59.2, 14.7, and $26.1 \%$, respectively. We can therefore assume that the lower and longer horizontal plateau reflects the titration process of silanol functional groups on the $\mathrm{SiO}_{2}$ surface, and the upper plateau corresponds to silandiol groups. According to (Méndez et al., 2003), the intervals of changes in the dissociation constants are $\mathrm{pK}_{1}=3.51-4.65$ and $\mathrm{pK}_{2}=6.17-6.84$, respectively. The same values of constants of dissociation for silanol and silandiol groups of silica were measured and published in (Nawrocki, 1997; Neue, 2000). The presence of silanol and silandiol groups on the surface of the studied $\mathrm{SiO}_{2}$ was thus identified.

From two types of the xerogels studied $\left(\mathrm{TiO}_{2}\right.$ and $\left.\mathrm{SiO}_{2}\right)$ electrical potential of $\mathrm{TiO}_{2}$ xerogel is slightly more than that of $\mathrm{SiO}_{2}$ xerogel (Fig.3). There was found a small horizontal plateau in the range of pHintr between 3.75 and 4.25 on the titration curve for NR R1 near the $\mathrm{SiO}_{2}$ surface. From this plateau $\mathrm{pK}$ a values for silanol groups were determined. They were found to be equal to $3.95 \pm 0,07$ within the zone of constant $\mathrm{pH}_{\text {int }}$ values (Molochnikov et al., 1996). The measured values of $\mathrm{pK}$ are in good agreement with those determined before for silicas using chromatography(Méndez et al., 2003) and the method of $\mathrm{pH}$ probe in different silicacontaining samples (Golovkina et al., 2008). At lesser $\mathrm{pH}$ values this curve goes near (but slightly righter) than the calibration curve of the above-mentioned NR. As seen from the figure, the surface of $\mathrm{SiO}_{2}$ xerogel carries a small negative charge which is characteristic for the sample before titrating silanol groups. The lack of horizontal plateaus on the titration curves of NR R1 for the $\mathrm{TiO}_{2}$ xerogel indicates the fact of titration of its functional groups at $\mathrm{pH}$ above 7. It can be explained by the presence of mainly terminal $\mathrm{OH}^{-}$-groups with basic properties on a surface of $\mathrm{TiO}_{2}$ xerogel. The range of their titration lies above the zone of sensitivity of the NR used.

When studying acidity inside organic sorbents or hydrogels, $\mathrm{pH}$ probes are placed into water, which penetrates into a solid due to sample swelling. In this case, the probes occur in water environment far away from the chains of organic (synthetic ion-exchange resins) or inorganic $\left(\mathrm{TiO}_{2}\right.$ and $\mathrm{SiO}_{2}$ hydrogel, xerogel) polymers. 
The particles of nanostructured oxides in diameter of several $\mathrm{nm}$ possess extremely large surface (the ratio of the number of atoms on the surface of a nanoparticle to the number of atoms located inside the particle is equal to 1/7). Therefore, a pH-sensitive NR surrounded by water molecules can approach the hydrated surface of nanoparticles rather closely. It was expected that they as probes and labels would appear to be sensitive to SEP, which would make it possible to estimate its value.

The dependences of NR ionization constants on the surface electric potentials and the polarity of media were reported by Fromherz (Fromherz , 1989) and Khramtsov et al. (Khramtsov et al., 1992) for fluorescent $\mathrm{pH}$ indicators and for $\mathrm{pH}$-sensitive NRs, respectively, as follows:

$$
\Delta \mathrm{pK}_{\mathrm{a}}=\Delta \mathrm{pK}_{\mathrm{a}}^{\mathrm{el}}+\Delta \mathrm{pK}_{\mathrm{a}}^{\mathrm{pol}}
$$

where $\Delta \mathrm{pK}_{\mathrm{a}}$ is the total shift in the $\mathrm{pKa}$ of an NR occurring in a sample relative to that of the NR in an aqueous solution and $\Delta \mathrm{pK}_{\mathrm{a}}^{\mathrm{el}}$ and $\Delta \mathrm{pK}_{\mathrm{a}}^{\mathrm{pol}}$ are the shifts in the $\mathrm{pK}$ a of the NR occurring in the sample, which are due to th electric potential arising on the sample surface and to a change in the polarity of the medium relative to the polarity of the NR aqueous solution, respectively.

$$
\begin{gathered}
\Delta \mathrm{pK}_{\mathrm{a}}^{\mathrm{el}}=-\mathrm{e} \times \varphi / 2.3 \mathrm{k} \times \mathrm{T} \\
\Delta \mathrm{pK}_{\mathrm{a}}^{\mathrm{pol}}=\mathrm{b} \times\left(\varepsilon-\varepsilon_{\mathrm{HOH}}\right)
\end{gathered}
$$

where $\varphi$ is the electrostatic potential, e is the electron charge, $\mathrm{k}$ is the Boltzmann constant, $\mathrm{T}$ is absolute temperature, $\mathrm{b}$ is a proportionality coefficient dependent on the radical nature, $\varepsilon$ is the medium permittivity, and $\varepsilon$ нон is the permittivity of water.Figures 6 and 7 demonstrate the results of studying nano- structured $\mathrm{TiO}_{2}$. The measurements were performed using $\mathrm{R} 3$ probe at $\mathrm{pH} \approx 5.5$, which was close to the $\mathrm{PZC}$ of $\mathrm{TiO}_{2}$ (5.7) (Poznyak et al., 1999), and $\mathrm{R} 2$ probe at $\mathrm{pH}$ $\approx 4.3$. Near the surface of $\mathrm{TiO}_{2}$ nanostructured particles, the titration curves of the radicals are shifted to the left, whereas, for $\mathrm{TiO}_{2}$ hydrogel and xerogel (Fig.3), a shift to the right was observed. At present, we can not find any explanation for such principal different shift in the titration curves for $\mathrm{TiO}_{2}$-based samples. The $\mathrm{TiO}_{2}$ hydrogel obtained by hydrolysis was washed out with water, removing acidic components of the initial salts. Hereafter, the samples were prepared at different drying temperatures. The samples of xerogels and nanostructured oxides were dried at $100^{\circ} \mathrm{C}$ and $200{ }^{\circ} \mathrm{C}$, respectively.

As was mentioned above, the shift of the titration curve for $\gamma-\mathrm{Al}_{2} \mathrm{O}_{3}$ to the left corresponds to the positive charge of the particle surface that, in principle, correlates with the data obtained at $\mathrm{pH}$ below PZC. The left-shift (toward more acidic solutions) of the titration curve of the probe located near the surface of $\mathrm{TiO}_{2}$ nanoparticles indicates that the surface electric potential is also positive. No changes were found in the hyperfine splitting constants $a_{N}$ for both deprotonated and protonated R3 radicals (Fig. 6). The curves of titration of NR 


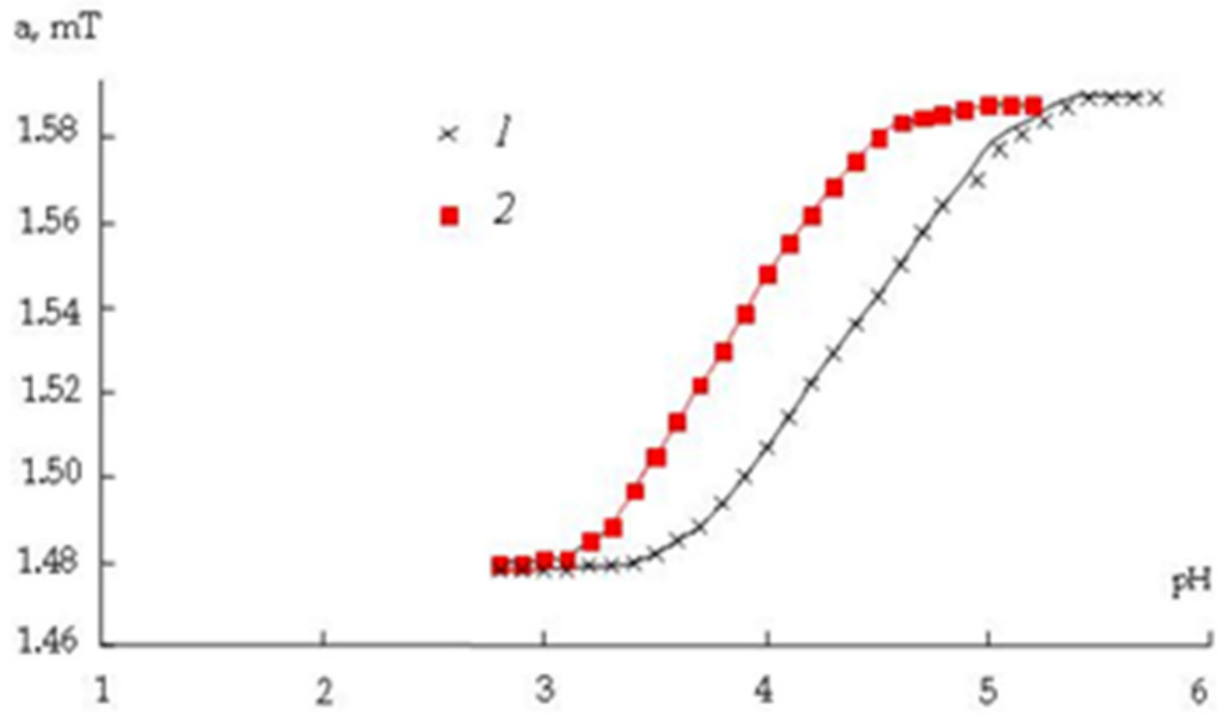

Figure 6. Titration curves for NR R3 in bulk aqueous solution (calibration curve) (1) and near the surface of nanostructured $\mathrm{TiO}_{2}(2)$ at $25^{\circ} \mathrm{C}$ and $\mu=0.1$

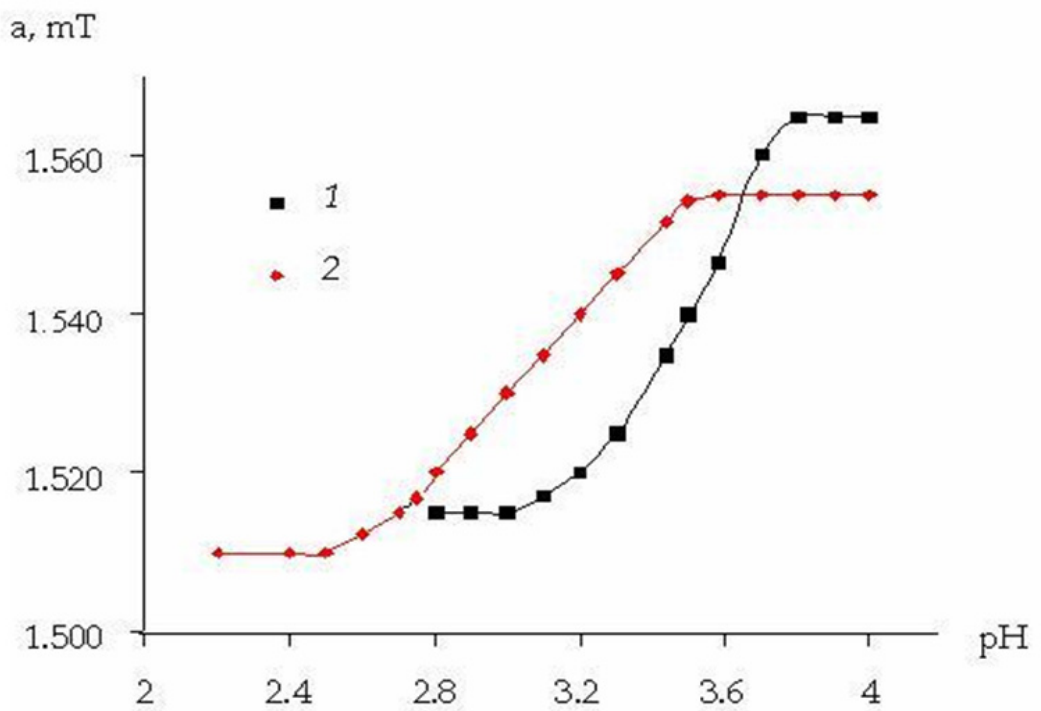

Figure 7. Titration curves for NR R2 (1) in bulk aqueous solution and (2) near the surface of nanostructured $\mathrm{TiO}_{2}$ at $25^{\circ} \mathrm{C}$ and $\mu=0.1$. The amount of $\mathrm{Cu}^{2+}$ ions sorbed in the pores of $\mathrm{TiO}_{2}$ is 0.36 $\mathrm{mmol} / \mathrm{g}$ of the sample 
$\mathrm{R} 3$ in the solution (curve 1) and near the surface of the nanostructured $\mathrm{TiO}_{2}$ (curve 2) begin and end at the same value of parameter $a$ characterizing the hyperfine splitting constant $a_{\mathrm{N}}$ for the protonated and deprotonated forms of NR. This fact shows that there are no changes in the polarity of the medium on the surface of nanostructured $\mathrm{TiO}_{2}$ relative to the external solution, and the term $\Delta \mathrm{pK}_{\mathrm{a}}{ }^{\mathrm{pol}}$ calculated by formula (7) is reduced to zero (Khramtsov et al., 1992). Thus, the shift in pKa is determined by the electric potential of nanoparticle surface alone $\left(\Delta \mathrm{pK}_{\mathrm{a}}=\Delta \mathrm{pK}_{\mathrm{a}}^{\mathrm{el}}\right)$. The calculation by formula (6) gives $\varphi=31.7 \mathrm{mV}$ at the point of $\mathrm{R} 3$ probe location. It should be stressed that the calculated $\varphi$ value is not the electric potential of $\mathrm{TiO}_{2}$ nanoparticle surface, but it only characterizes the electric field generated by a nanoparticle at the site where the radical fragment $-\mathrm{N}-\mathrm{O} \bullet$ of $\mathrm{R} 3$ probe is located.

\subsection{2. $\mathrm{Cu}^{2+}$-containing samples}

For $\mathrm{TiO}_{2}$ hydrogel, $\mathrm{pH}$ values of the external solution, which is in contact with the hydrogel $\left(\mathrm{pH}\right.$ ext), and of those inside the hydrogel $\left(\mathrm{pH}_{\mathrm{int}}\right)$ during the sorption of $\mathrm{Cu}^{2+}$ ions from copper(II) chloride and nitrate solutions are found to be different (Fig. 5). It was observed that the anions of these copper(II) salts had no effect on the acidity of a medium. In the process of sorption $\mathrm{Cu}^{2+}$ ions are involved in the chemical interaction with the active centers of the hydrogel (Kharchuk et al., 2004) that manifests itself both in the parameters of the ESR spectra of $\mathrm{Cu}^{2+}$ in the hydrogel and in the impossibility of washing out sorbed $\mathrm{Cu}^{2+}$ ions from the hydrogel by $\mathrm{Na}^{+}$and $\mathrm{Ca}^{2+}$ nitrate solutions. According to the data obtained, initially, $\mathrm{pH}$ int is lower by 1.5 units than $\mathrm{pHext}$ (Table 3). As the amount of $\mathrm{Cu}^{2+}$ ions in the hydrogel grows, pHint decreases (Fig. 5), and, beginning with an amount of $0.24 \mathrm{mmol} / \mathrm{g}$ of the gel, it coincides with $\mathrm{pH}_{\text {ext. }}$ Thus, the acidity inside the original hydrogel sample is considerably lower than that of the equilibrium external solution. Similar regularities were found for granulated organic ion-exchange resins (Kovaleva et al., 2000). For KB-2 × 4 cationite in a mixed $\mathrm{H}^{+}-\mathrm{Na}^{+}$form, it was found that in the process of absorption of copper, the acidity of the external solution diminishes, while the acidity inside the sorbent remains unchanged until a certain amount of $\mathrm{Cu}^{2+}$ ions in the ionite is attained, with this content being dependent on the fraction of $\mathrm{Na}^{+}$form of the cationite When this value is exceeded, the acidity inside the sorbent begins to decrease and $\mathrm{pH}_{\text {ext }}$ and $\mathrm{pH}_{\text {ext }}$ values for the ionite become equal at a certain degree of saturating with $\mathrm{Cu}^{2+}$-ions. For $\mathrm{TiO}_{2}$ hydrogel, the equalization of $\mathrm{pH}$ values is also observed, but the horizontal plateau with a constant $\mathrm{pH}$ int value on the titration curve of NR is not observed. The constant $\mathrm{pHint}$ values for KB-2 $\times 4$ cationite are explained by the buffer properties of its $\mathrm{H}^{+}-\mathrm{Na}^{+}$mixed form. $\mathrm{TiO}_{2}$ hydrogel has no buffer properties, and the acidity increases smoothly with a rise in the amount of sorbed $\mathrm{Cu}^{2+}$ ions.

For nanostructural $\mathrm{TiO}_{2}$, in the presence of sorbed $\mathrm{Cu}^{2+}$ ions, at $\mathrm{pH}$ close to 4.3 (Fig. 7), like in the case of pure nano $-\mathrm{TiO}_{2}$ (Fig.6), a shift of the titration curve toward lower $\mathrm{pH}$ values is observed; however, the hyperfine splitting constant an decreases (the titration curve is shifted downward). The decrease in an is probably related to a lower polarity (the effective permittivity of the medium) near the nanoparticle surface where the probe is located. The theory predicts that the permittivity of a medium must have the same effect on both 
electroneutral (the deprotonated form of the radical) and charged (the protonated form) species (Griffith et al., 1974). We found that the rise in the $\mathrm{Cu}^{2+}$ amount from 0 to 0.36 $\mathrm{mmol} / \mathrm{g}$. of the gel results in an increase in the $\Delta \mathrm{pK}$ a value. The shift of this curve $(\Delta \mathrm{pK})$ to the left is significantly smaller that for NR R3, although the change from the PZC to $\mathrm{pH} 4.3$ and the incorporation of $\mathrm{Cu}^{2+}$ ions must enhance the positive charge of the nanoparticle surface and, according to formula (6), increase in $\Delta \mathrm{pK}_{\mathrm{a}}$. In accordance with formula (7), a reduction in the permittivity near the surface of $\mathrm{TiO}_{2}$ particles compared to $\varepsilon \mathrm{HOH}$, which causes the observed decrease in an, must also shift the titration curve to the left.

Hence, the explicit inconsistency between the determined $\Delta \mathrm{pK}$ a values for NR R2 and NR R3 radicals and the theoretical predictions is established. We relate this difference to a larger distance of NR R2 from the surface compared to NR R3; this is possible because NR R2 has a substituent in position 4, which is presumably positioned toward the surface due to the tendency of its amino groups to protonation (or complexation with $\mathrm{Cu}^{2+}$ ions sorbed on the surface). Thus, the $-\mathrm{N}-\mathrm{O} \bullet$ fragment of the radical turns out to be removed from the surface of $\mathrm{TiO}_{2}$ by the chain length of this substituent. The electric potential induced on the $-\mathrm{N}-\mathrm{O} \bullet$ fragment will decrease with the distance from the surface and will be inversely proportional to the distance from this surface, when it is represented as, for example, a plane. The small NR R3 radical can approach the nanoparticle surface much closer and, therefore, it is affected more strongly by the electrostatic potential of the $\mathrm{TiO}_{2}$ surface. The sorption of $\mathrm{Cu}^{2+}$ ions on the surface of nanoparticles increases the charge of the latter. The observed shift of the titration curve (Fig. 7) and the broadening of the ESR spectra of these radicals attest to the orientation of the substituent in position 4 of NR R2 toward the surface and to the interaction between amino groups of the substituent and the $\mathrm{Cu}^{2+}$ ions sorbed on the nanoparticle surface.

\subsection{Organic supports of composite and hybride materials}

For PC and MCC, the titration curves of NR R1 were found to be shifted to the left of the calibration curve (Fig. 2, 3 ), indicating a posiive charge on the surface (Kovaleva et al., 2000 ; Molochnikov et al., 2007). Hydroxyl groups of celulose most likely play the role of surface bases whose protonation gives the surface a positive charge.

\subsection{Solid-phase composites based on $\mathrm{SiO}_{2}, \mathrm{TiO}_{2}$ and cellulose powder}

\subsubsection{Pure systems}

As shown in Fig. 8 and 9, the titration curves of NR R1 in the $\mathrm{CMs} \mathrm{TiO}_{2}-\mathrm{PC}$ with 70 (not shown) and $53 \%$ wt. $\mathrm{TiO}_{2}$ and in the $\mathrm{SiO}_{2}-\mathrm{PC}$ with 68 and $35 \%$ wt. $\mathrm{SiO}_{2}$ (unprotonated parts) are shifted to the right relative to the calibration curve, as in the case of $\mathrm{TiO}_{2}$ and $\mathrm{SiO}_{2}$ xerogels. For $\mathrm{CMs}$ based on $\mathrm{SiO}_{2}, \mathrm{TiO}_{2}$ and cellulose powder $\Delta \mathrm{pH}=\mathrm{pH} \mathrm{H}_{\mathrm{ext}}-\mathrm{pH}$ int decreased (the curves are shifted to the left relative to those of pure xerogels) as the PC content in the samples increased; this corresponds to a decrease in the negative charge of the CM surface. This is because of the lower acidity of cellulose compared to the acidity of the solution (cellulose has basic alcohol functional groups in its structure) and the positive charge of its surface (Parshina, 2011). 


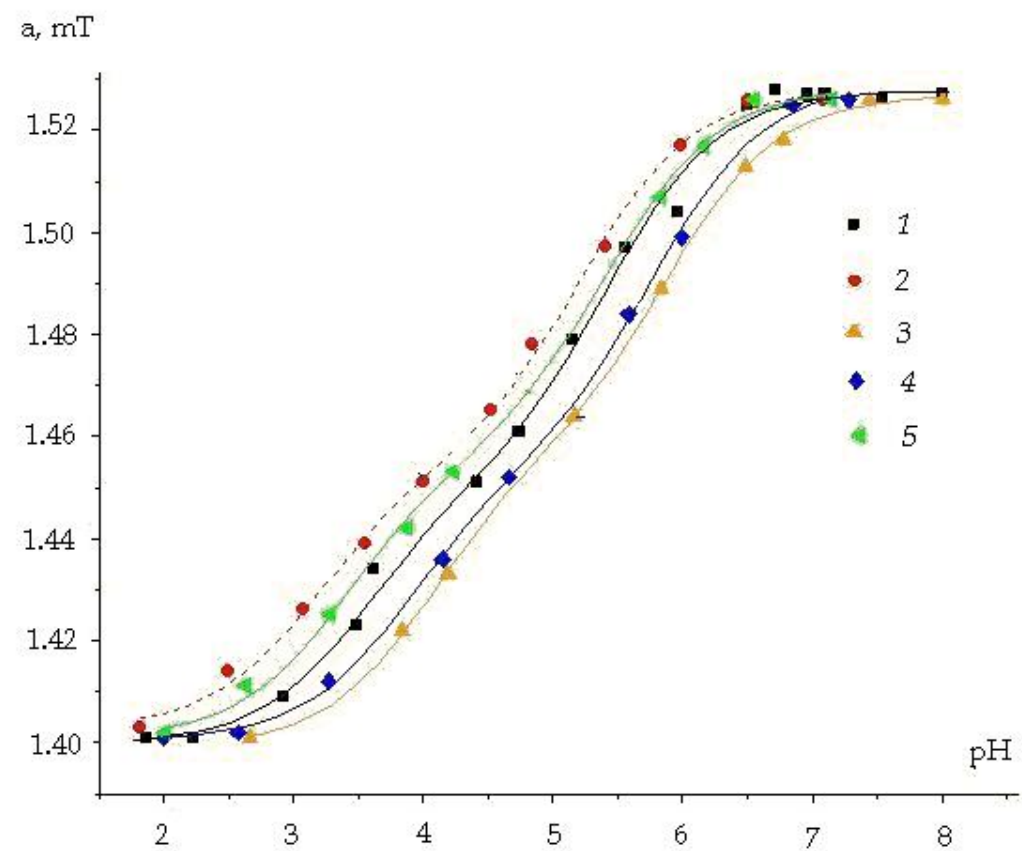

Figure 8. Titration curves for NR R1 in bulk solution (1), $\mathrm{PC}(2), \mathrm{TiO}_{2}$ xerogel (3) и $\mathrm{CMs} \mathrm{TiO}_{2}: \mathrm{PC}(53 \%$ wt. $\left.\mathrm{TiO}_{2}\right)(4)$ and $\mathrm{TiO}_{2}: \mathrm{PC}(43 \%$ wt.TiO 2$)(5)$

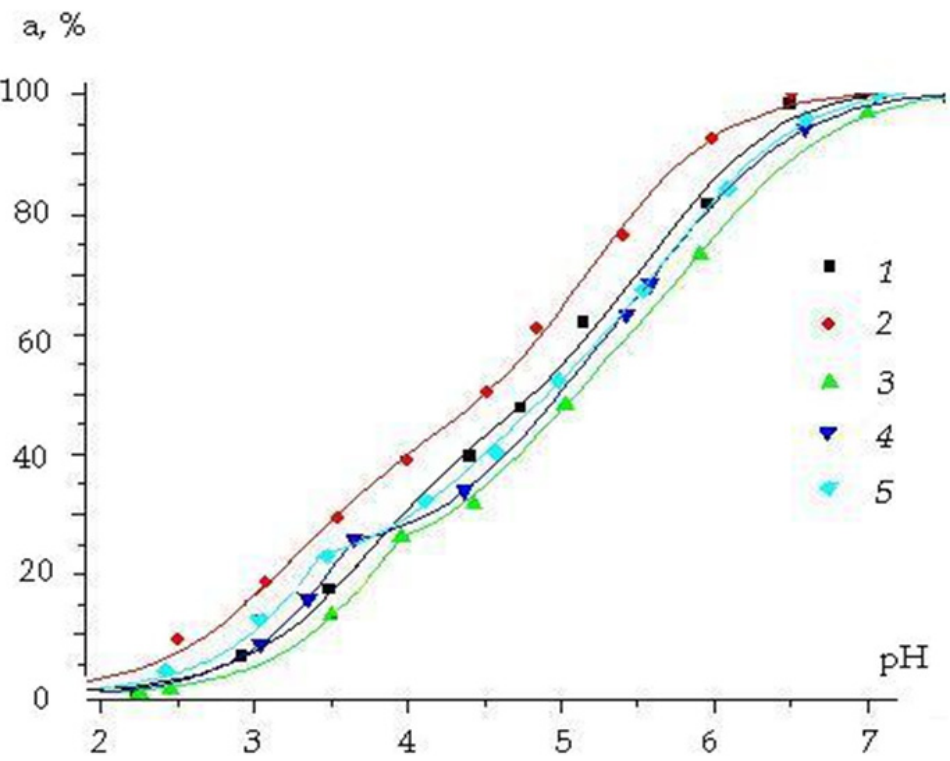

Figure 9. Titration curves for NR R1 in bulk solution (calibration curve) (1), $\mathrm{PC}$ (2), $\mathrm{SiO}_{2}$ xerogel (3) and

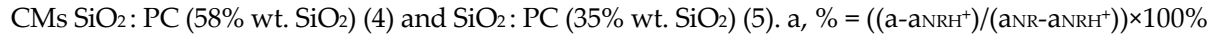


This proves that a surface of the composites studied carries lesser negative charge as compared to that of pure xerogels. The left-shift of the curve of NR R1 in $\mathrm{CM} \mathrm{TiO}_{2}-\mathrm{PC}$ with $43 \%$ wt. $\mathrm{TiO}_{2}$ relative to the calibration curve can be explained by initial positive charge of the surface of this $\mathrm{CM}$ due to binding $\mathrm{H}^{+}$ions. Hence, SEP of $\mathrm{CMs}$ based on $\mathrm{TiO}_{2}$ and $\mathrm{PC}$ is varied over a wide range and even changes its sign from negative to positive as an increase in PC content. From the curves plotted, we notice that a decrease in percentage of $\mathrm{TiO}_{2}$ xerogel in CMs from от 53\% до $43 \%$ leads to a $\mathrm{pH}$ intr greater than a $\mathrm{pHext}$. This fact can be explained by positive charge of a surface of cellulose due to the presence of alcohol groups in its structure.

For all the synthesized $\mathrm{CMs}$ based on $\mathrm{SiO}_{2}$ xerogel and PC after complete protonating silanol groups, the titration curves of NR R1 were shifted to the left relative to the calibration curve and, hence, a surface of the samples studied remained positively charged (Fig.9). Unlike the composites based on $\mathrm{TiO}_{2}$ and $\mathrm{PC}$, an increase in a percentage of $\mathrm{PC}$ in the $\mathrm{SiO}_{2}-\mathrm{PC}$ composites leads to changing a surface charge from positive to negative with increasing $\mathrm{pH}_{\text {ext }}$ (above the horizontal plateau on the titration curves) due to dissociation of functional groups. Thus, the incorporation of PC into the samples doesn't change acidity of silanol groups and doesn't make a polarizing effect on the $\mathrm{SiO}-\mathrm{H}$ bond. The length of the horizontal plateau slightly increases in the accordance with the amount of silanol groups and the percentage of $\mathrm{PC}$ in the $\mathrm{CMs}$ based on $\mathrm{SiO}_{2}$. This can be caused by the increased dispersity of $\mathrm{SiO}_{2}$ due to rising in $\mathrm{S}_{\mathrm{sp}}$ of the CMs (Table 1).

By varying the cellulose percentage in the composites and $\mathrm{pHext}$ values, $\mathrm{pH}$ int values and SEP can be selected over a wide range. This information is needed for optimization of the conditions for $\mathrm{pH}$-dependent adsorption and catalytic processes through a choice of $\mathrm{CM}$ with a certain $\mathrm{pH}$ int and SEP as catalyst substrate and adsorbent.

\subsection{2. $\mathrm{Cu}^{2+}$-containing composites}

The sorption of $\mathrm{Cu}^{2+}$ on the $\mathrm{TiO}_{2}$ and $\mathrm{SiO}_{2}$ xerogels and on the related $\mathrm{CMs}$ is accompanied by a change in the $\mathrm{pH}$ in their phases. However, the dependences of $\mathrm{pHext(int)}$ vs cCu (amount of sorbed $\mathrm{Cu}^{2+}$ ions) for the above- mentioned types of xerogels and the $\mathrm{CMs}$ based have some differences (Fig.10, 11).

From these figures we notice that :

- $\mathrm{pH}_{\text {int }}$ is different from $\mathrm{pH}_{\text {ext, }}$ and with no $\mathrm{Cu}^{2+}$ in an external solution (ccu=0), $\mathrm{pH}$ ext is greater than $\mathrm{pH}$ int.

- With an increase in the amount of $\mathrm{Cu}^{2+}$ in the $\mathrm{CMs}$, both the $\mathrm{pHext}$ and $\mathrm{pH}$ int descrease.

- There is a horizontal plateau on the dependences of $\mathrm{pH}_{\text {int }}$ on $\mathrm{ccu}$ in the range of sorbed $\mathrm{Cu}^{2+}$ from 0.15 up to $0.3 \mathrm{mmol} \mathrm{Cu}{ }^{2+} / \mathrm{g}$. $\mathrm{TiO}_{2}, \mathrm{SiO}_{2}$ xerogel, within which $\mathrm{pH}$ int remains constant with increasing in ccu.

- At greater ccu pHint and $\mathrm{pH}_{\text {ext }}$ come closer and become almost equal. 


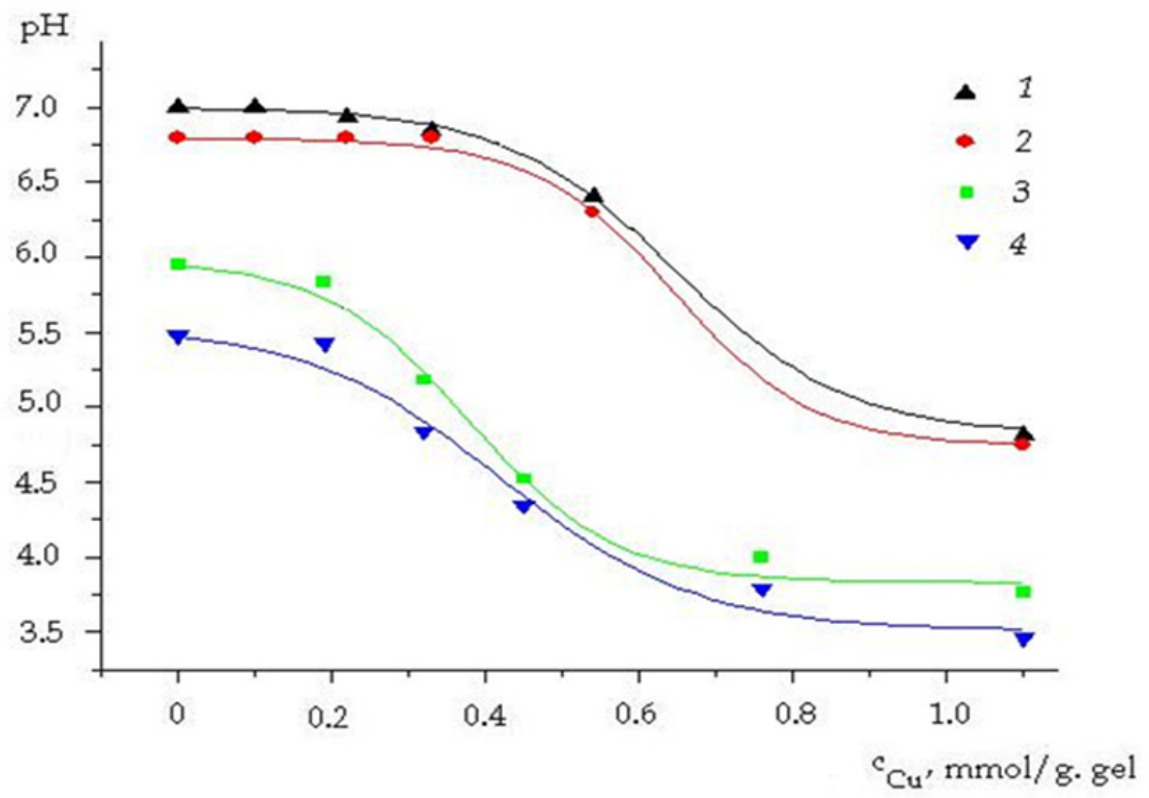

Figure 10. $\mathrm{pH}$ of external solution ( $\mathrm{pH}$ ext) (curves 1,3) and near the surface ( $\mathrm{pHint}$ (curves 2,4) of $\mathrm{TiO}_{2}$ xerogel (curves 1, 2) and the $\mathrm{TiO}_{2}$ : $\mathrm{PC}\left(47 \%\right.$ wt. $\mathrm{TiO}_{2}$ ) composite (curves 3,4) vs.ccu

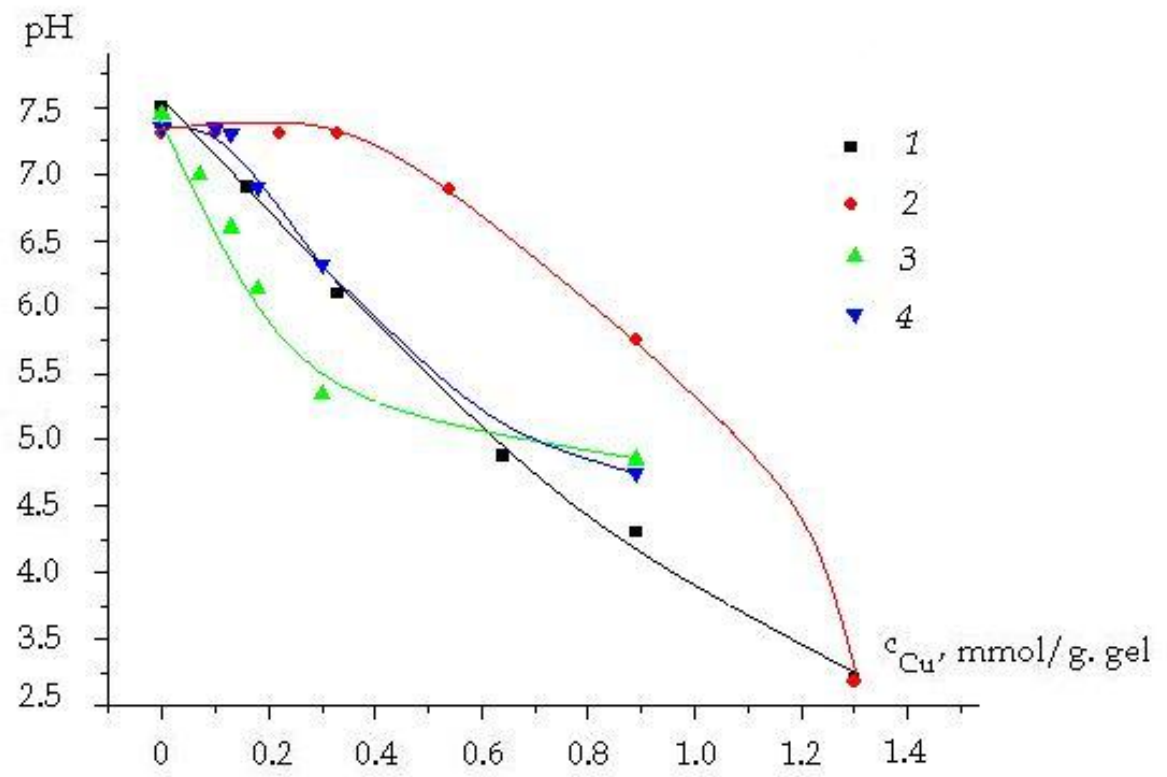

Figure 11. $\mathrm{pH}$ of external solution ( $\mathrm{pHext}$ (curves 1,3 ) and near the surface ( $\mathrm{pH}$ int) (curves 2,4$)$ of $\mathrm{SiO}_{2}$ xerogel (curves 1,2) and the $\mathrm{SiO}_{2}: \mathrm{PC}\left(68 \% \mathrm{wt} . \mathrm{SiO}_{2}\right)$ composite (curves 3,4) vs.ccu 
The increase in acidity of external solution, first of all, is caused by the hydrolysis of $\mathrm{Cu}^{2+}$ at the initial $\mathrm{pH}$ ext equal to 6-7 and is accompanied by intense release of $\mathrm{H}^{+}$ions. The lesser $\mathrm{pH}$ int values as compared to $\mathrm{pHext}$ for both types of xerogels and the related CMs can be explained by a surface negative charge. A surface of the samples studied attracts $\mathrm{H}^{+}$ions in its double electrical layer to compensate this charge. Also an increase in acidity of both external and internal (near the surface) solutions is caused by the fact that the sorption of $\mathrm{Cu}^{2+}$ ions is accompanied by intense release of $\mathrm{H}^{+}$ions into them. The increase in the acidity of a medium due to the competition of $\mathrm{H}^{+}$ions almost completely suppresses the ion exchange sorption of $\mathrm{Cu}^{2+}$. An analogous tendency was previously observed for organic ion-exchange resins (as grains) and $\mathrm{TiO}_{2}$ hydrogel (Kovaleva et al., 2000 ; Molochnikov et al., 2004).

The presence of the horizontal plateaus on the curves $\mathrm{pHint}_{\mathrm{vs}} \mathrm{ccu}$ (Fig. 9) indicates the buffer properties of the $\mathrm{TiO}_{2}$ xerogel and the $\mathrm{TiO}_{2}$ : PC samples by analogy with the same properties of the mixed $\mathrm{H}^{+}-\mathrm{Na}^{+}$form of the KB-2 $\times 4$ cationite (Kovaleva et al., 2000). The greater is percentage of PC in a sample, the shorter is the horizontal plateau on the abovementioned curves. The buffer effect of the $\mathrm{TiO}_{2}$ xerogel and the related CMs is caused by the existence of some amount of deprotonated functional groups in the samples before the sorption of $\mathrm{Cu}^{2+}$. The complexation of $\mathrm{Cu}^{2+}$ ions with these groups occurs first of all and does not lead to the release of $\mathrm{H}^{+}$ions, which would reduce both $\mathrm{pHext}$ and $\mathrm{pHint}$. In addition, releasing of hydroxide groups as a result of dissociation of molecules of $\mathrm{Cu}(\mathrm{OH})_{2}$ responsible for complexation with functional groups of a surface of xerogel can retard decreasing $\mathrm{pH}$ with increasing $\mathrm{CCu}$.

Unlike $\mathrm{TiO}_{2}$ systems, for $\mathrm{SiO}_{2}$ and the related $\mathrm{CMs}$ pHint values were found to be more than pHext ones (Fig. 11). Apparently, this differance can be explained by the significant differences in $\mathrm{pK}$ a of functional groups of $\mathrm{SiO}_{2}$ and $\mathrm{TiO}_{2}$ oxides. $\mathrm{pK}$ a values of silanol groups $(3.95 \pm 0.07)$ are significantly lower than $\mathrm{pHext}$ from which sorption of $\mathrm{Cu}^{2+}$ has been conducted. Therefore, silanol groups are completely dissociated and $\mathrm{H}^{+}$ions don't exchange with $\mathrm{Cu}^{2+}$ ions during complexation. Hence, no functional groups can neutralize $\mathrm{OH}^{-}$groups forming during breakdown of $\mathrm{Cu}(\mathrm{OH})_{2}$ molecules. As a result, $\mathrm{pHint}$ values (near a surface of samples) have high values.

As the titratuon curves for $\mathrm{TiO}_{2}$-based CMs don't contain the horizontal plateaus as well as pure systems, hence, $\mathrm{pK}$ a values of active acidic centers of a surface of these materials are out of zone of sensitivity of the NR used (greater than 7) (Fig. 8). Therefore, these centers are mainly in the protonated form before sorption of $\mathrm{Cu}^{2+}$-ions. During complexation $\mathrm{Cu}^{2+}$-ions exchange with $\mathrm{H}^{+}$ions of functional groups releasing them into external solution. Hence, $\mathrm{pH}$ int became less than $\mathrm{pH}$ ext. It shows up in a general decrease $\mathrm{pH}$ (both $\mathrm{pH}$ int and $\mathrm{pH}$ ext) with increasing CCu (Fig. 10 ).

\subsection{Hybrid organo-inorganic materials based on the chitosan- $\mathrm{Al}_{2} \mathrm{O}_{3}$, chitosan- $\mathrm{SiO}_{2}$, and cellulose -chitosan-systems}

Hybrid systems were obtained in accordance with the scheme (Fig.12) 

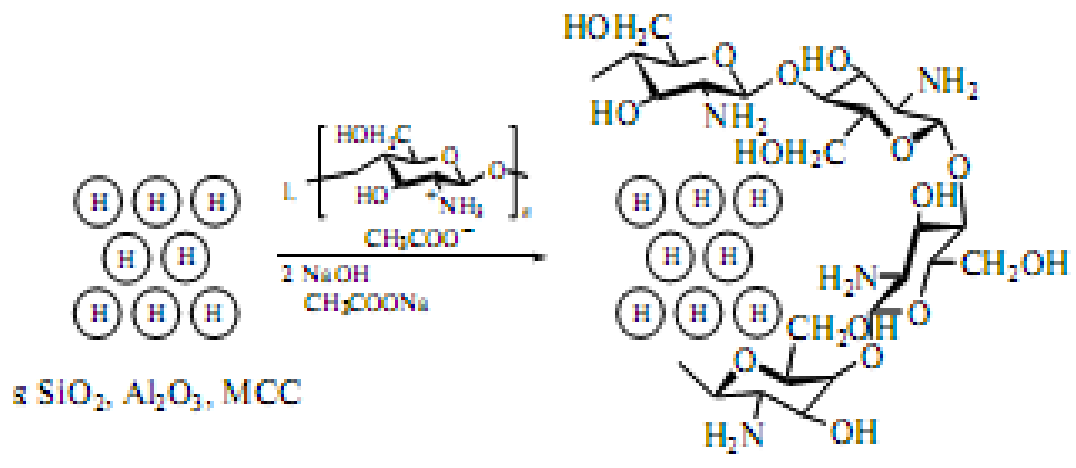

Figure 12. Scheme for obtaining hybrid organo-inorganic materials. s -support

The compositions of the obtained hybrid systems were characterized by elemental analysis (Table 2). According to the obtained data, the reactivity of substrates was different and declined in the order $\mathrm{MCC}>\mathrm{Al}_{2} \mathrm{O}_{3}>\mathrm{SiO}_{2}$, since the compositions of the obtained hybrids in the case of inorganic oxides do not correspond to the molar ratios of the initial components.

The presence of chitosan molecules on the surface of the obtained systems was confirmed by the IR spectra, which contain characteristic absorption bands at 1652 and $1555 \mathrm{~cm}^{-1}$ corresponding to residual acetoamide groups of the polymer.

Since the obtained composites have to be electroneutral, we must assume that in the case of $\mathrm{SiO}_{2}$, the substrate, being a weak acid, forms an ionic bond with the chitosan's amino group. In case of $\mathrm{Al}_{2} \mathrm{O}_{3}$, the same situation is possible, but some of the chitosan's amino and hydroxyl groups are involved in complex-forming with aluminum. In the case of MCC, the interaction occurs through hydrogen bonds.

NR were used as $\mathrm{pH}$-probes to obtain a more detailed characterization of the surface structure of hybrid systems, their acid-base properties.

A comparison of the ESR spectra of NR R1 in solution and in the samples studied showed that in all cases, there was an isotropic signal which indicated the lack of covalent bonds between the NR and the sample surface and the presence of this radical near the surfaces of particles (Fig. 4, spectrum 1).

\subsubsection{Pure hybride systems}

Analysis of the structure of the $\mathrm{Al}_{2} \mathrm{O}_{3}$-chitosan system according to the adsorbed probe molecules of the nitroxyl radical showed that coating the initial $\alpha-\mathrm{Al}_{2} \mathrm{O}_{3}$ substrate with chitosan leads to a slight increase in the surface negative charge, as was confirmed by the shift of the NR titration curve to the right (Fig. 13). The titration curves of $\alpha-\mathrm{Al}_{2} \mathrm{O}_{3}$ and $\mathrm{Al}_{2} \mathrm{O}_{3}$-chitosan are not parallel to the calibration curve at low $\mathrm{pH}$ values due to the gradual dissolving of $\alpha-\mathrm{Al}_{2} \mathrm{O}_{3}$ particles in weakly acidic media, as has been noted during investigations of samples containing aluminate ions (Iller, R., 1979 ; Golovkina, 2009). 


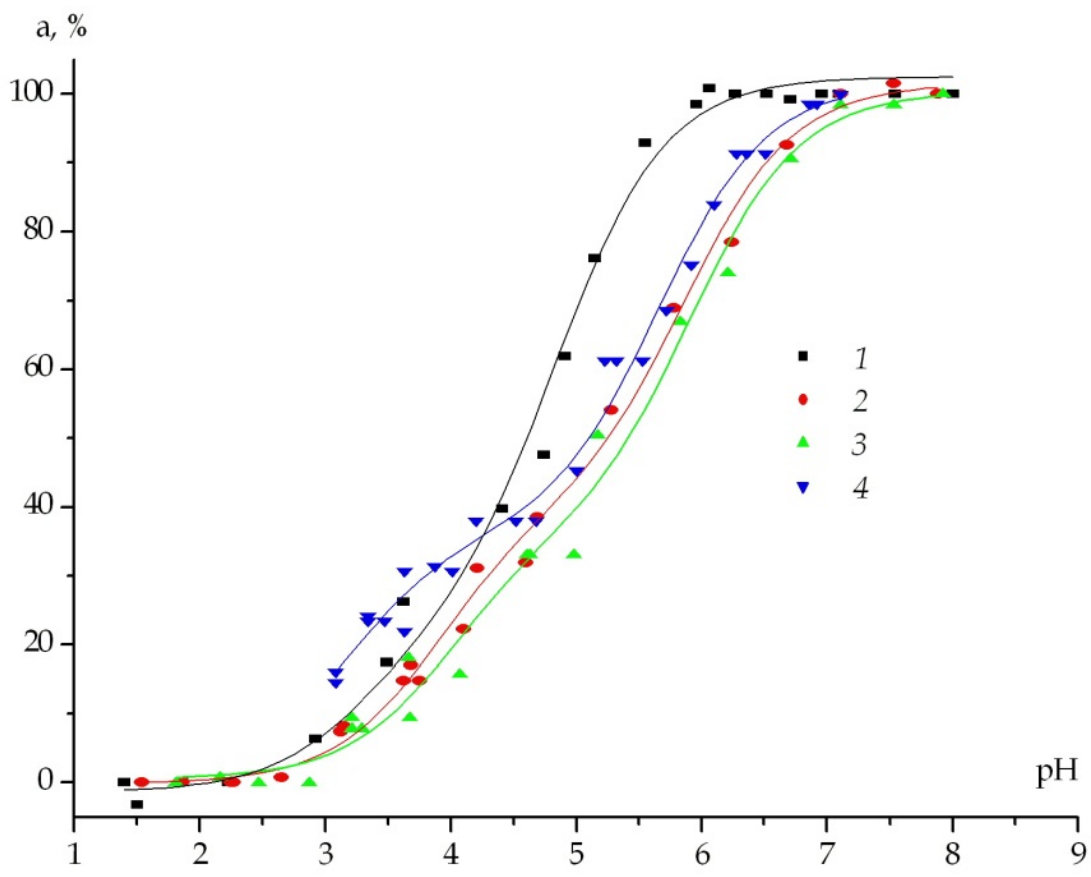

Figure 13. Titration curve for NR R1 in aqueous bulk solution ( calibration curve) (1), near the surface of $\mathrm{Al}_{2} \mathrm{O}_{3}(2)$, hybride $\mathrm{Al}_{2} \mathrm{O}_{3}-$ chitosan $(3)$ and $\mathrm{Al}_{2} \mathrm{O}_{3}-$ chitosan- $\mathrm{Co}^{2+}(4)$ systems . a, \% = ((a-anRH $\left.{ }^{+}\right) /($anRaNRH $\left.H^{+}\right) \times 100 \%$

For the $\mathrm{SiO}_{2}$-chitosan system, the NR titration curve overlaps the corresponding curve for $\mathrm{SiO}_{2}$ values within the horizontal section of the titration curve for silandiol groups in the range of high $\mathrm{pH}$ (Fig. 14). We can correspondingly claim that in this $\mathrm{pH}$ region, the surfaces of the samples all have the same charge, demonstrating that chitosan has no influence on the $\mathrm{SiO}_{2}$ surface. If $\mathrm{pH}$ is decreased below 6, the titration curve for the $\mathrm{SiO}_{2}$-chitosan system shifts to the right of the corresponding curve for $\mathrm{SiO}_{2}$, indicating the negative charge of the surface. The horizontal pleteau of the titration curve for silanol groups is lower in the case of the $\mathrm{SiO}_{2}-$ chitosan system ( $\mathrm{pH} 4.5-5)$, and the $\mathrm{pKa}$ value for silanol groups in the presence of chitosan falls slightly. A similar reduction in this parameter has been observed during modification of the surface of mesoporous molecular sieves based on $\mathrm{SiO}_{2}$ with aluminate and borate ions (Golovkina et al., 2009). Below the titration curve plateau for silanol groups $(\mathrm{pH}<4.2)$, the titration curves of $\mathrm{SiO}_{2}$ and $\mathrm{SiO}_{2}$-chitosan overlap again, indicating a similar surface charge.

The deposition of chitosan on MCC causes the titration curve to shift to the right of to both the calibration curve and the NR titration curve of the initial MCC sample (Fig. 15), demonstrating the negative charge of the surface, as was observed for the $\mathrm{Al}_{2} \mathrm{O}_{3}$-chitosan and $\mathrm{SiO}_{2}$-chitosan systems. A peculiarity of this substrate is the recharging of the surface, from positive for MCC to negative for the MCC-chitosan system during chitosan 
deposition. In this case, the type of change in the surface charge occurring upon a reduction in $\mathrm{pH}$ is the same for both the MCC and the MCC-chitosan systems. Changing symbatically with the curve typical of the initial MCC sample, the titration curve for the MCC-chitosan system almost overlaps the calibration curve in the acidic region $(\mathrm{pH} \leq 4.5)$. In this $\mathrm{pH}$ range, the potential of the MCC-chitosan system surface is therefore close to zero.

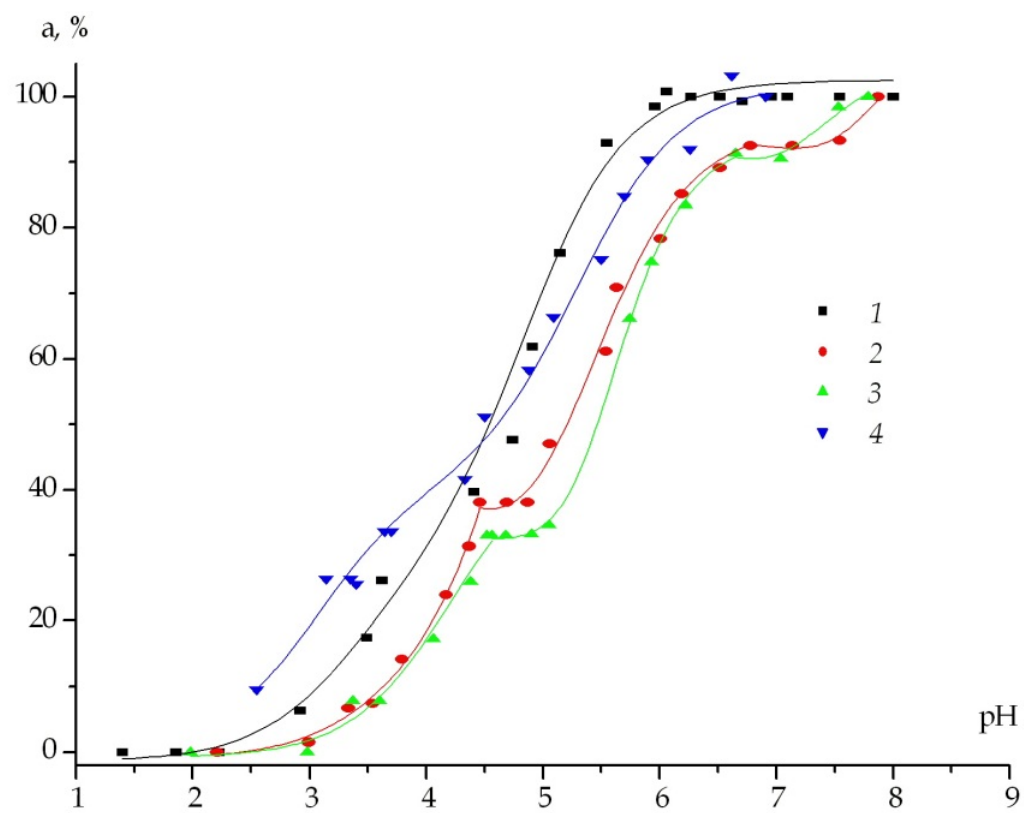

Figure 14. Titration curve for NR R1 in aqueous bulk solution ( calibration curve) (1), near the surface of $\mathrm{SiO}_{2}$ (2), of the hybride $\mathrm{SiO}_{2}-$ chitosan (3), of the $\mathrm{SiO}_{2}-$ chitosan- $\mathrm{Co}^{2+}(4)$ systems. a, \% $=\left(\left(\mathrm{a}-\mathrm{anRH}^{+}\right) /(\mathrm{anR}-\right.$ aNRH $\left.{ }^{+}\right) \times 100 \%$

The deposition of chitosan on the substrate always causes the titration curve of the radical near the surface of hybrid material to shift to the right; i.e., it leads to a negative charge on the surface. While the deposition of chitosan leads to relatively slight changes in the surface potential in the case of inorganic substrates, these changes are so great in the case of MCC that they even lead to changes in the surface charge.

Some of differences in the behavior of titration curves for chitosan-containing materials on the inorganic substrates that occur in the range of high $\mathrm{pH}$ values could be due to the close pKa values of the silandiol groups of the $\mathrm{SiO}_{2}$ substrate $\left(\mathrm{pK}_{\mathrm{a}}=6.5-6.8\right)$ and of the chitosan $\left(\mathrm{pK}_{\mathrm{a}}=6.42\right.$ (Skorik et al., 2003)). When the $\mathrm{pH}$ falls, amino groups of chitosan or silandiol groups become protonated and form hydrogen bonds with one another. As a result, the charge of the initial substrate surface and that of the hybrid material become similar. During further protonation of silandiol and amino groups at the same $\mathrm{pH}$ range, this interaction becomes impossible, and the surface charge of the $\mathrm{SiO}_{2}$-chitosan hybrid material becomes more negative than that of the $\mathrm{SiO}_{2}$. 


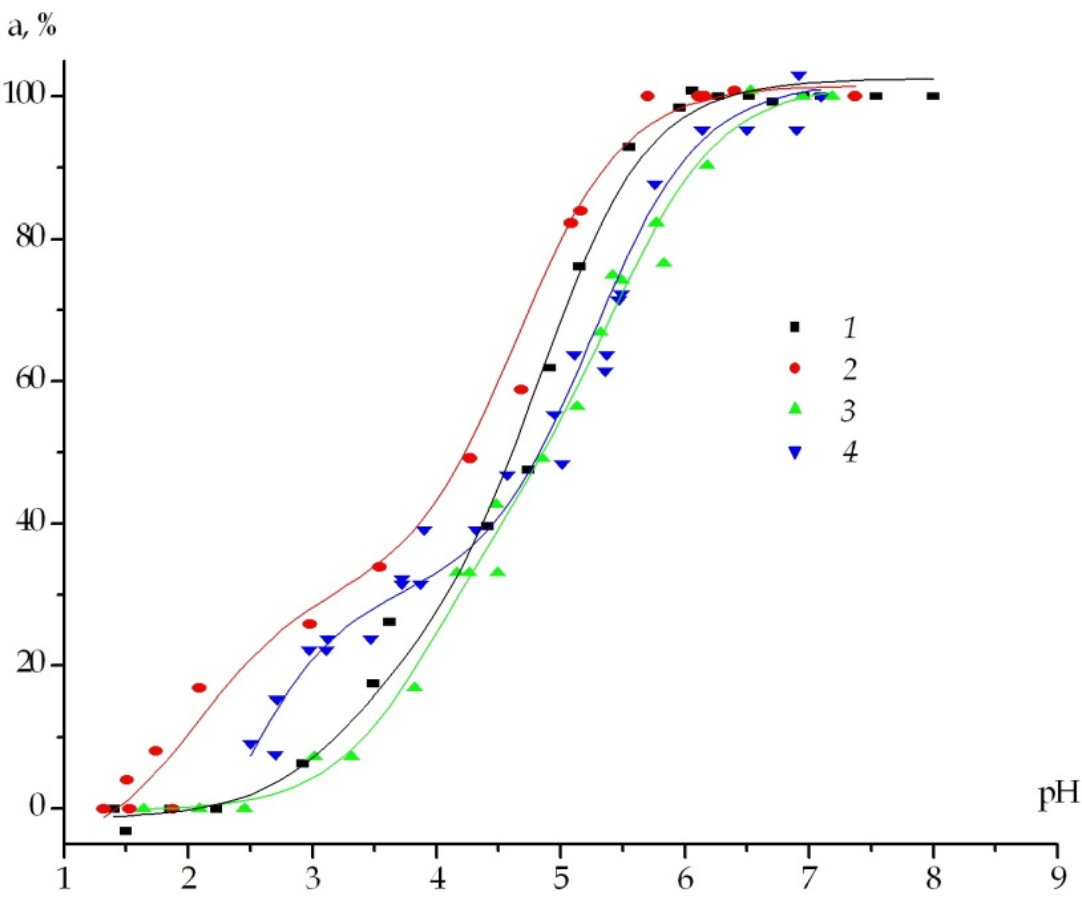

Figure 15. Titration curve for NR R1 in aqueous bulk solution ( calibration curve) (1), near the surface of MCC (2), of the hybride MCC- chitosan (3), of the MCC- chitosan-Co ${ }^{2+}(4)$ systems . a, $\%=\left(\left(a-a_{n N H}\right) /(\right.$ anRanRH $\left.\left.^{+}\right)\right) \times 100 \%$

This is in complete agreement with the relative positions of the radical titration curves for $\mathrm{Al}_{2} \mathrm{O}_{3}$ and $\mathrm{Al}_{2} \mathrm{O}_{3}$-chitosan. It must be emphasized that the $\mathrm{pK}_{\mathrm{a}}$ dissociation value of hydroxyl groups of $\mathrm{Al}_{2} \mathrm{O}_{3}$ is higher, and lies outside the radical sensitivity range.

Deposits of chitosan on the MCC substrate breaks it into smaller particles (Table 2), due most likely to the recharging of the surface from positive to negative. Chitosan molecules are appreciably smaller in size than MCC molecules, that is why a negative charge leads to increased repulsion inside large MCC particles, to their disintegration, and finally to an increase in the total surface area of the material. Chitosan thus plays the role of a disaggregating surfactant. In case of inorganic substrates, the deposition of chitosan leads to an increase in the particle size, and consequently to a decrease in their surface area (Table 1). Chitosan is therefore a weakly aggregating surfactant as to inorganic substrates.

The pKa value for amino groups of chitosan is 6.42 (Skorik et.al, 2003). In the investigated $\mathrm{pH}$ range $(\mathrm{pH} \leq 6)$, polymer molecules must consequently be positively charged due to the formation of $-\mathrm{NH}_{3}{ }^{+}$ammonium groups. If chitosan molecules were adsorbed on the surface of inorganic oxides so that the protonated amino groups were on the material surface, this kind of adsorption would be reflected in the titration curves of the modified samples and 
would cause the titration curve to shift to the left of the titration curves of the initial oxides. Since this did not happen, we can assume that during the formation of hybrid material, chitosan amino groups form weak hydrogen bonds or Van der Waals bonds with functional groups of substrates (organic or inorganic), leading to an arrangement of chitosan molecules in which glucosamine rings are turned in the direction of the substrate.

\subsection{2. $\mathrm{Co}^{2+}$-containing hybride systems}

The presence on the support surface of a polymer that is capable of acquiring metal ions of high coordination numbers is needed to fix these ions more firmly on metal-containing hybride materials. This role was played by chitosan on the surfaces of the inorganic $\left(\mathrm{SiO}_{2}\right.$, $\mathrm{Al}_{2} \mathrm{O}_{3}$ ) and organic (MCC) supports. $\mathrm{Co}^{2+}$ ions were sorbed from an aqueous ethanol solution (Fig. 16).

The composition of the studied systems was characterized by elemental analysis. According to the data, the sorption capacity of the hybrid systems relative to $\mathrm{Co}^{2+}$ ions is different and declines in the following order: $\mathrm{SiO}_{2}>\mathrm{Al}_{2} \mathrm{O}_{3}>$ MCC. We should note that in this case, there is a difference between the mechanisms of binding ions for different supports, since their surfaces have the same coating influencing the process.

As follows from the elemental analysis, chitosan plays the role of a complexing agent. In this case, all amino groups are involved in the coordination by cobalt ions (ratio Co: $\mathrm{NH}_{2}=1: 1-1.5$ ).

In the case of the $\mathrm{Al}_{2} \mathrm{O}_{3}$-chitosan system, some of the amino groups do not participate in the complexation, but the $\mathrm{Co}: \mathrm{Cl}$ ratio corresponds to the composition of the initial salt that provides the coordination mechanism for binding cobalt ions (Fig.17). In the case of the $\mathrm{SiO}_{2}$-chitosan system, the $\mathrm{Co}: \mathrm{Cl}$ ratio is $\sim 1$. The need to obey the law of electroneutrality for the obtained hybrid systems requires assuming that the support, in addition to being a weak acid, also plays a coordinating role with respect to $\mathrm{Co}^{2+}$ ions, which accords with the covalent mechanism of binding $\mathrm{Co}^{2+}$ ions (Fig. 17). In the case of the MCC-chitosan system, metal ions are sorbed as a basic salt, and hydroxyl groups on the surface provide weaker coordination binding than $\mathrm{Al}_{2} \mathrm{O}_{3}$.

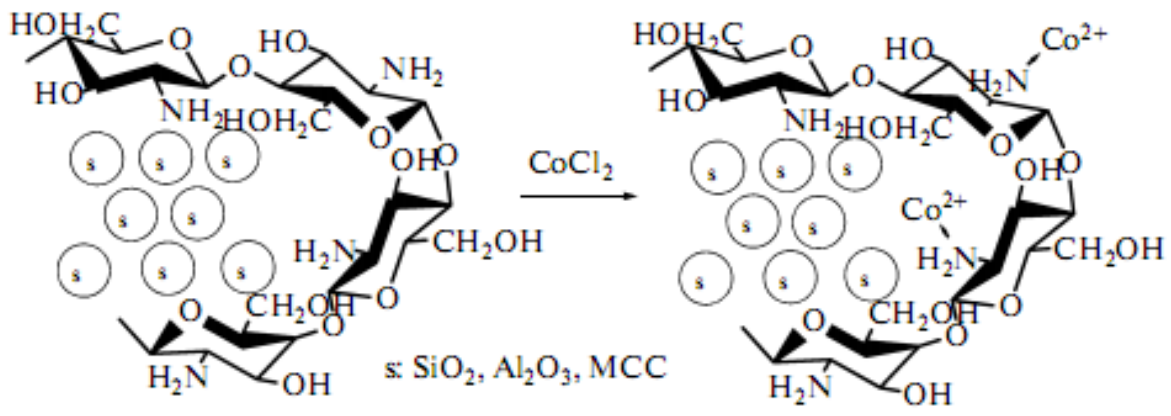

Figure 16. Scheme for synthesis of cobalt-containing hybrid systems. s - support 


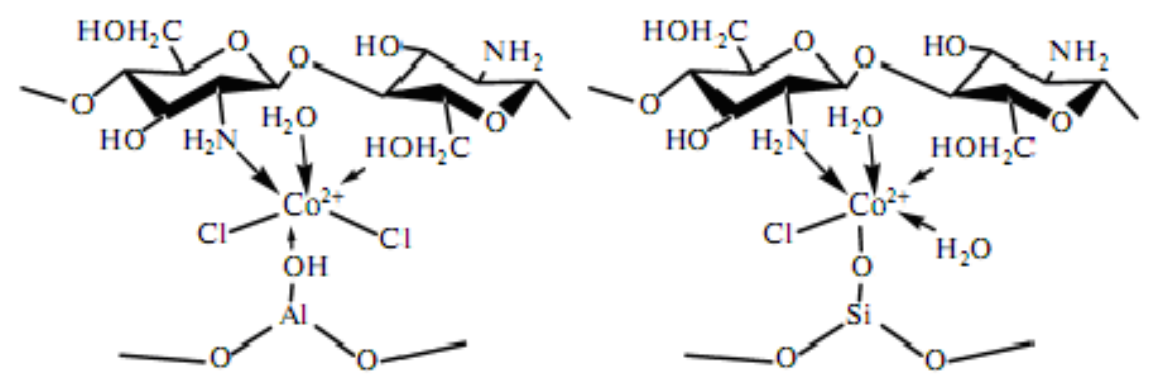

Figure 17. Scheme for the mechanism of binding $\mathrm{Co}^{2+}$ by hybrid systems

The elemental composition of the surface shows that chitosan does not cover it completely and some part of the functional groups remains on the support surface in free form. The more complex structure of the surface of hybrid system was characterized by investigating its acid-base properties via ESR spectroscopy of the NR used as $\mathrm{pH}$ probes. The titration curves of NR R1 on the surface of the $\mathrm{Co}^{2+}$-containing system are shown in Figs. 13-15. The shift in these curves relative to the calibration curve left or right allows us to determine whether the surface has a positive or negative charge, respectively (Kovaleva et al., 2000 ; Molochnikov et al., 2007).

The technique for introducing $\mathrm{Co}^{2+}$ ions into the hybrid materials from the ethanol solutions could lead to the formation of sediments of basic cobalt chloride or chloride-alcoxide micelles on the surface of these materials. In the case of the MCC-chitosan (Fig. 15) and $\mathrm{Al}_{2} \mathrm{O}_{3}$-chitosan (Fig. 13) systems, the titration curves of the cobalt-containing materials at $\mathrm{pH}$ $>5$ are shifted slightly to the left relative to the titration curves of the initial samples. Consequently, the occurrence of basic cobalt chloride on the surface of these materials does not lead to a change in the surface charge, but changes its value slightly. This is due to the effective neutralization of a positive charge of $\mathrm{Co}^{2+}$ ions by negative chloride and hydroxide ions. In order to confirm our hypothesis, we present the published data on studying the sorption of $\mathrm{Co}^{2+}$ ions from aqueous solutions and on the nature of the interaction between the metal center and amino groups of chitosan. According to (Minimisawa et al., 1999) maximum adsorption starts to decrease with increasing $\mathrm{pH}$ due to the formation of cobalt hydroxocomplexes. The maximum sorption of cobalt ions by chitosan found at $\mathrm{pH}$ 6-8 in (Silva et.al, 2008) is in good agreement with the data from (Minimisawa et al., 1999) and is determined by the formation of $\mathrm{Co}(\mathrm{OH})_{2}$ phase or slightly soluble basic salts. No chemical interaction with amino groups of chitosan occurs in this case (Zhao et al., 1998).

The $\mathrm{SiO}_{2}-$ chitosan system behaves differently. Even at the highest $\mathrm{pH}$ values, the titration curve of the sample modified with cobalt (Fig. 17) was appreciably shifted to the left relative to the NR curve of the initial sample, although it remains to the right of the calibration curve. Accordingly, the formation of the chloride hydroxyl cobalt micelles immediately leads to a considerable reduction in the negative surface charge of the $\mathrm{SiO}_{2}$-chitosan system. The different behavior of the titration curve for system III (Table 2) is most likely associated 
with the initially lower amount of $\mathrm{Cl}^{-}$ions in the cobalt micelles $(\mathrm{Co}: \mathrm{Cl}=1: 1)$, i.e., to its higher amount of $\mathrm{OH}-$ ions. Acid sites on the $\mathrm{SiO}_{2}$ surface (silanol groups) also likely interact with the basic cobalt chloride particles precipitating on the surface, thereby replacing the $\mathrm{Cl}^{-}$ions. In both cases, the titration curve must shift left due to the neutralization of the negative surface charge. In the study of the samples in the aqueous medium at high $\mathrm{pH}$ values, the transformation for systems I-III (Table 2) thus occurs; hydration of the surface, followed by hydrolysis leading to the formation of colloidal particles based on chloro-hydroxo complexes of $\mathrm{Co}^{2+}$ ions, is observed.

These micelles of $\mathrm{Co}^{2+}$ chloro-hydroxocomplexes begin to dissolve at $\mathrm{pH} \leq 5$ for all investigated systems. The dependence of sorption of cobalt ions on $\mathrm{pH}$ (Minimisawa et al., 1999) shows that the maximum adsorption starts to decline at $\mathrm{pH}<5$, and $\mathrm{Co}^{2+}$ ions in the solution are in the form of aqua complexes (Zhao et al., 1998). The latter are sorbed by the chitosan primary amino groups, thereby charging the surface positively; in this case, the titration curves of systems I-III (Table 2) (Figs.13-15) are shifted left relative to the corresponding curves for the initial samples and to the calibration curve. A further reduction in $\mathrm{pH}$ leads to the neutralization of $\mathrm{OH}^{-}$groups, and no further changes in $\mathrm{pH}$ near the particle surface are observed upon a change in $\mathrm{pH}$ ext.

This indicates the presence of a horizontal plateau on the titration curve. The value of the horizontal section is lower for system III than for systems I and II (Table 2), since some of the $\mathrm{OH}^{-}$groups are replaced by residues of silicic acid. At high $\mathrm{pH}$ values, $\mathrm{Co}^{2+}$ ions initially cause a substantial decrease in the negative surface charge for the case of system III; their transformation into the form coordinated by the chitosan - $\mathrm{NH}_{2}$ groups thus influences the surface charge to a lesser degree upon declining $\mathrm{pH}$. Our results indicate the participation of chitosan amino groups in the complexation with $\mathrm{Co}^{2+}$ ions. During the interaction of the hybrid materials with the $\mathrm{Co}^{2+}$-containing solution, at least a part of glucosamine rings are consequently turned outward and are capable of becoming ligands.

\section{Conclusions}

$\mathrm{pH}$-sensitive NRs gave reliable information on the local acidity of solutions in and the charge of a surface on pure and metal containing inorganic and organo-inorganic materials and systems and allowed to estimate an electric potential near the surface of $\mathrm{TiO}_{2}$ nanoparticles.

The differences between the acidities of external solutions ( $\mathrm{pHext}$ ) and inside pores (or near the surface) of all the studied materials and systems ( $\mathrm{pHint}$ ) were found.

The method of spin $\mathrm{pH}$ probes allowed to determine the ionization constants of characteristic functional groups of $\mathrm{SiO}_{2}$-based systems from the horizontal plateaus corresponding to the constant $\mathrm{pH}$ int in the samples.

An increase in concentration of $\mathrm{H}^{+}$ions (a decrease in pHint) in solutions located inside $\alpha$ $\mathrm{Al}_{2} \mathrm{O}_{3}, \mathrm{TiO}_{2}$ hydrogel and near the surface of the $\mathrm{BS}-50$ type $\mathrm{SiO}_{2}, \mathrm{TiO}_{2}$ and $\mathrm{SiO}_{2}$ xerogels ; the 
related CMs and hybrid materials; metal-containing systems, as compared to those of external solution can be explained by releasing $\mathrm{H}^{+}$ions due to dissociation of acidic functional groups, exchange them with metal ions and the partial desruption of hydrogen bonds. It leads to negative charge of a surface of the above-mentioned objects. A decrease in concentration of $\mathrm{H}^{+}$ions (an increase in $\mathrm{pH}$ int) as compared to those of external solution were characteristic for $\gamma-\mathrm{Al}_{2} \mathrm{O}_{3}$ and cellulose matrixes. This resulted from binding $\mathrm{H}^{+}$-ions by the surface of $\gamma-\mathrm{Al}_{2} \mathrm{O}_{3}$ and $\mathrm{MCC}$ and $\mathrm{PC}$ with basic functional groups such as $-\mathrm{AlOH},-\mathrm{AlO}$ and $\mathrm{OH}^{-}$, respectively. As a result, a surface gains a positive charge.

The sorption capacity of $\mathrm{Cu}^{2+}$ ions depends on a surface charge of the oxides gels, xerogels and the related $\mathrm{CMs}$ studied and decreases as a negative surface charge reduces. The sorption of $\mathrm{Cu}^{2+}$ ions on the surface of nanoparticles of nanostructural $\mathrm{TiO}_{2}$ increases the charge of the latter. An increase in a percentage of $\mathrm{PC}$ in the $\mathrm{SiO}_{2}-\mathrm{PC}$ composites leads to an increase in the amount of silanol groups as a result of increasing in dispersivity of $\mathrm{SiO}_{2}$ particles and specific surface $\left(\mathrm{S}_{\mathrm{sp}}\right)$ of the samples, and to reducing a negative surface charge up to zero, and even its reversing. It led to the formation of $\mathrm{Cu}(\mathrm{OH})_{2}$.

The deposition of chitosan on the substrate always creates a negative charge on the surface. While the deposition of chitosan leads to relatively slight changes in the surface potential in the case of inorganic substrates such as $\mathrm{Al}_{2} \mathrm{O}_{3}$ and $\mathrm{SiO}_{2}$, these changes are so great in the case of MCC that they even lead to changes in the surface charge.

The charge of the surface of $\mathrm{Co}^{2+}$-modified organo-inorganic hybrid materials at different $\mathrm{pH}$ int was found to effect on the composition and structure of $\mathrm{Co}^{2+}$-containing surface compounds.

The modification of a surface of powder cellulose with nanostructured $\mathrm{SiO}_{2}$ and $\mathrm{TiO}_{2}$ xerogels, aluminum oxides, silica and MCC with acidic functional groups and chitosan makes it possible to adjust the local acidity and surface charge over a wide range.

The study of the surface of organo-inorganic composites and hybrid materials and systems using $\mathrm{pH}$-sensitive nitroxyl radicals allows also to reveal regularities in changing their properties during further modification. In addition, this method enables us to describe qualitatively the processes of structure formation in these systems and their effect on catalytic activity in different $\mathrm{pH}$-dependent reactions.

The calculated $\varphi$ value $(31.7 \mathrm{mV})$ was found not to be the electric potential of $\mathrm{TiO}_{2}$ nanoparticle surface, but it only characterizes the electric field generated by a nanoparticle at the site where the radical fragment $-\mathrm{N}-\mathrm{O} \bullet$ of $\mathrm{NR}$ is located. Once the anisotropic spectra of NR in nanostructured oxides are simulated, an electical potential of a surface can be determined. When measuring the SEP of solids, the knowledge of the distance between a radical and a surface is of principal importance. The fixation of $\mathrm{pH}$-sensitive NRs on the surface of nanoparticles with linkers of a known length can solve this problem. This will allow one to calculate the potential immediately on the surface of nanoparticles and to compare the calculation results with the experimental data on the electrokinetic potentials. 


\section{Author details}

Elena Kovaleva*

Ural Federal University,Russia

Leonid Molochnikov

Ural State Forest Engineering University, Russia

\section{Acknowledgement}

The authors are very grateful to :

- Prof. A.M. Volodin and Prof. A.I. Kulak for synthesizing and supplying aluminum oxides and nanostructured $\mathrm{TiO}_{2}$ both original and modified with $\mathrm{F}-$ and $\mathrm{SO}_{4}{ }^{2-}$ groups,

- Dr. I.A. Kirilyuk and Prof. I.A. Grigor'ev for synthesis of pH-sensitive nitroxide radicals,

- Dr. A.B. Shishmakov, Mrs. Yu. V. Mikushina and Dr. E. V. Parshina for synthesizing $\mathrm{TiO}_{2}$ and $\mathrm{SiO}_{2}$ hydrogels and xerogels, pure and $\mathrm{Cu}^{2+}$-containing solid-phase composites based on nanostructured $\mathrm{SiO}_{2}$ and $\mathrm{TiO}_{2}$ and powder cellulose,

- Mr. A.V. Mechaev for synthesis and characteization of pure and $\mathrm{Co}^{2+}$-containing hybrid organo-inorganic materials based on the chitosan- $\mathrm{SiO}_{2}$, chitosan- $\mathrm{Al}_{2} \mathrm{O}_{3}$, and -chitosancellulose systems,

- Prof. A.I. Kokorin, Dr. A.V. Pestov and Prof. Yu.G. Yatluk for fruitful discussion of the study results.

The studies presented in this manuscript were financially supported by the Ministry of the Education of the Russian Federation (2007-2011, Theme 01.2.007-06425).

\section{References}

Airoldi C. \& Monteiro, O. A. C. (2000). Chitosan-Organosilane Hybrides-Synthesis, Characterization, Copper Adsorption and Enzyme Immobilization. J. Appl. Polym. Sci., Vol. 77, No.4, (July 2000), pp. 797 -804, ISSN 1097-4628

Borbat, P.P., Milov, A.D., Samoilova, R.I. et al. (1990). Vliyanie Razmera Por na Vrashchatel'nuyu Podvizhnost' Spinovogo Zonda v Silikagel'Ach (Effect of Pore Size on Rotational Motion of Spin Probe in Silica Gels). Kolloidn. Zh. (Russ.Colloid J.), Vol. 52, No.2, (February 1990), pp. 341-345, ISSN 1061-933X (in Russian)

Budanova, N. Yu., Shapovalova, E. N. \& Lopatin, S. A. (2001). Issledovanie Uderzhivayushchei i Razdelyaushei Sposobnosti Silikagelei, Midifitsirovannych Novym Chiral'nym Selektorom - Nizkomolekulyarnym Khitosanom (Study of Retentivity and Separating Capacity of Silica Gels Modified With a Novel Chiral

\footnotetext{
${ }^{*}$ Corresponding Author
} 
Selector - Low Molecular Chitosan) Vestn. Mosk. Univ., Ser. Khim. Vol. 42, No.2, pp.112115, ISSN 0579-9384 (in Russian)

Buyanov, R.A.(Ed.).(1998). Kataliz i Katalizatory: Fundamental'nye Issledovaniya Instituta kataliza im. G.K. Boreskova Sib. Otd. Ross. Akad. Nauk (Catalysis and Catalysts. Fundamental Works of Boreskov Institute of Catalysis), Siberian Branch of the Russian Academy of Sciences, ISBN 5769201320, Novosibirsk, Russia (in Russian)

Corma A., Concepción, P., Domínguez, I. et al. (2007). Gold Supported on a Biopolymer (Chitosan) Catalyzes the Regioselective Hydroamination of Alkynes. J. Catal. ,V.251, No. 1, (1 October, 2007), pp. 39-47, ISSN 0021-9517

Fromherz, P. (1989). Lipid Coumarin Dye as a Probe of Interfacial Electrical Potential in Biomembranes. Methods Enzymol., Vol. 171, pp. 376-387, ISSN 0076-6879

Golovkina, E.L., Kovaleva, E.G., Molochnikov, L.S. et al. (2008). Method of Spin Probe for Study of MMS SBA-15. Zhurnal Khromatographicheskikh I Sorbtsyonnykh Processov (Russ.J. Sorp. Chromat. Proc.), Vol. 8, No. 6, (June 2008), pp. 971-985, ISSN 1680-0613 (in Russian)

Golovkina E. L. (2009). Electrochemical Properties of Mesoporous Molecular Sieves: Measurements and Study Using Spin pH-probe Method, Ph. D. Dissertation in Chemistry, Ural State Forest Engineering University, Yekaterinburg, Russia (defended at the Chelyabinsk State Pedagogical University, Chelyabinsk) (in Russian)

Griffith, O.H., Dehlinger, P. J. \& Van, S. P. (1974). Shape of the Hydrophobic Barrier of Phospholipid Bilayers (Evidence for Water Penetration in Biological Membranes). J. Membrane Biol. V.15, No.1, (December 1974), pp. 159-192, ISSN 0022-2631

Hubbard, E.T., (Ed.) (2002). Encyclopedia of Surface and Colloid Science, Marcel Dekker, ISBN, New York

Huang, K., Liu, H., Dou, X. et al. (2003). Silica-Supported Chitosan-Osmium Tetroxide Complex Catalysed Vicinal Hydroxylation of Olefins Using Hexacyanoferrate (III) Ion as a Cooxidant. Polym. Adv. Technol., Vol. 14, No.4, (April 2003), pp. 366-370, ISSN 10991581

Iller, R. (1979). The Chemistry of Silica, Wiley, New York

Jeon, J.S., Sperline, R.P., Raghavan, S. et al. (1996). In Situ Analysis of Alkyl Phosphate Surfactant Adsorption at the Alumina/Aqueous Solution Interface. Colloids Surf., A, Vol. 111, No.1, (June 1996) , pp. 29, ISSN 0927-7757

Khan, R., Kaushik A., Solanki, P. R. et al. (2008). Zinc Oxide Nanoparticles-Chitosan Composite Film for Cholesterol Biosensor. Anal. Chim. Acta, Vol. 616, No.2, (June 2008), pp. 207-213, ISSN 0003-2670

Kharchuk, V.G., Buldakova, L.Yu., Shishmakov, A.B., et al. (2004). Oxidative Dehydrogenation of 2,3,5-Trimethyl-1,4-Hydroquinine in the Presence of Titanium Dioxide Hydrogel. Russ.J. General Chem., Vol. 74, No.1, (January 2004), pp. 101-104, ISSN 1070-3632

Khramtsov V. \& Weiner L. (1988). Proton Transfer Reactions in Free Radicals. Spin pH probes. Uspekhi Khimii (Russian Chem. Rev.), Vol. 57, No.9, (September 1988), pp. 824832, ISSN 0036-021X (in Russian) 
Khramtsov, V.V., Marsh, D., Weiner, L.M., et al. (1992). The Application of pH-sensitive Spin Labels to Studies of Surface Potential and Polarity of Phospholipid Membranes and Proteins. Biochim. Biophys. Acta, Vol. 1104, pp. 317-324, ISSN 0006-3002

Khramtsov, V.V. \& Volodarsky, L.B. (1998). Use of Imidazoline Nitroxides in Studies of Chemical Reactions: ESR Measurements of the Concentration and Reactivity of Protons, Thiols and Nitric Oxide. In : Biological Magnetic Resonance, Vol. 14, Spin Labeling, Berliner, L., Ed., p. 109-180, Plenum Press, ISBN 0306456443, New York

Kirilyuk, I.A., Bobko, A. A. Khramtsov, V. V. \& Grigor'ev, I. A. (2005). Nitroxides with Two $\mathrm{pK}$ Values-useful Spin Probes for $\mathrm{pH}$ Monitoring Within a Broad Range. Org. Biomol. Chem. Vol.3, No. 7, pp. 1269-1274, ISSN 1477-0520

Kovaleva, E.G., Molochnikov, L.S. \& Lipunov, I.N. (2000). The Influence of the Mixed $\mathrm{H}^{+}-$ $\mathrm{Na}^{+}$Form of KB- 2 Carboxyl Cationite and of $\mathrm{pH}$ within Ionite Grains on the State of $\mathrm{Cu}$ ( II) Ions and the Catalytic Properties of Ionite Catalysts Containing $\mathrm{Cu}(\mathrm{II})$. Rus.J.Phys. Chem., Vol. 74, No.8, (August, 2000), pp. 1262-1267, ISSN 0036-0244

Lidin, R.A., Andreeva, L.L. \& Molochko, R.A. (1987). Spravochnik Po Neorganicheskoi Khimii (Handbook on Inorganic Chemistry), Khimiya (Chemistry) ISBN 5-7245-1163-0, Moscow (in Russian)

Lisichkin, G.V., Fadeev, A.Yu., Serdan, A.A. et al. (2003) Khimiya Pryvitykh Poverkhnostnykh Soedinenii (Chemistry of Graft Surface Compounds), FIZMATLIT , ISBN 978-5-9221-0342-8, Moscow, Russia (in Russian)

Li, G., Jiang, Y., Huang, K., Ding, P. et al. (2008). Preparation and Properties of Magnetic $\mathrm{Fe}_{3} \mathrm{O}_{4}$-chitosan Nanoparticles. J. Alloys Compd., Vol. 466, No.2, (October 2008), pp. 451456, ISSN 0925-8388

Liu, X. Tokura D. S. \& Haruki, M. (2002). Surface Modification of Nonporous Glass Beads with Chitosan and Their Adsorption Property for Transition Metal Ions. Carbohydr. Polym.,Vol. 49, No.1, (July 20012), pp. 103-108, ISSN 0144-8617

Long, Y., Xu, T., Sun, Y. et al. (1999). Adsorption Behavior on Defect Structure of Mesoporous Molecular Sieves. Langmuir, Vol.15, No.19, (September 1999), pp. 61736178, ISSN 0743-7463

Martini, G., Bindi, M., Ottaviani, M.F., et al. (1985). Dipolar and Spin Exchange Effects in the ESR Spectra of Nitroxide Radicals in Solution: Part II. Water Solutions Adsorbed on Porous Silica Gels. J.Colloid Interface Sci. , Vol. 108, No.1, (November 1985), pp. 140- 148, ISSN 0021-9797

Mei, N., Xuguang,, L., Jinming, D. et al. (2009). Antibacterial Activity of Chitosan Coated Ag-loaded Nano-SiO2 Composites. Carbohydr. Polym.,Vol. 78, No.1, (August 2009), pp. 54-59, ISSN 0144-8617

Mekhaev, A.V., Pestov, A.V., Moloch nikov, L.S. et al. (2011). Investigation of the Structure of Chitosan Hybrid Systems by $\mathrm{pH}$-sensitive Nitroxide Radical. Russ. J. of Phys. Chem. A, Vol. 85, No.6, (June 2011), pp. 987-992, ISSN 0036-0244

Mekhaev, A.V, Pestov, A.V., Molochnikov, L.S. et al. (2011). Structure and Characteristics of Chitosan Cobalt-Containing Hybrid Systems, the Catalysts of Olefine Oxidation. Russ. J. Phys. Chem. A, Vol. 85, No.7, (July 2011), pp. 1155-1161., ISSN 0036-0244 
Méndez, A.L, Bosch, Roses M. \& Neue, U. D. (2003). Comparison of the Acidity of Residual Silanol Groups in Several Liquid Chromatography Columns. J. Chromatogr. A, Vol.986, No.1, (January 2003), pp. 33-44, ISSN 0021-9673

Mininisawa, H., Iwanami, H., Azai, N. et al. (1999). Adsorption Behavior of Cobalt(II) on Chitosan and Its Determination by Tungsten Metal Furnace Atomic Absorption Spectrometry. Anal. Chim. Acta., Vol. 378, No.3, (January 1999), pp. 279-285, ISSN $0003-$ 2670

Molochnikov, L.S., Kovalyova, E.G., Grigor'ev, I.A. et al. ( 1996). Determination of Acidity in the Interior of the Cross-linked Polyelectrolyte Grain by the Use of $\mathrm{pH}$-Sensitive probes, In Metal-Containing Polymeric Materials, Pittman, Ch.U. et al., pp. 395-401, Plenum Press, ISBN 10 0306452956, New York

Molochnikov, L. S., Kovalyova, E.G., Golovkina E.L. et al. (2007). Method of Spin Probe for Studying Acidity of Inorganic Materials. Russ.Colloid J. B, Vol. 69, No.6, (December 2007), pp. 769-776, ISSN 1061-933X

Molochnikov, L.S., Kovalyova, E.G., Grigor'ev, I.A., et al. (2004). A. Direct Measuring of $\mathrm{H}^{+}$ Activity Inside Cross-Linked Functional Polymers. J. Phys. Chem. B, 2004, Vol. 108, No.4, (December 2004), pp. 1302-1313, ISSN 1520-6106

Nawrocki, J. (1997). The Silanol Group and its Role in Liquid Chromatography J. Chromatogr. A, V. 779, No.1, (August 1997), pp. 29-71, ISSN 1520-6106

Neue, U. D. (2000). Silca Gel and Its Derivatization, In : Encyclopedia of Analytical Chemistry, Meyers, R. A. Ed.. Wiley, ISBN 9780470027318, Chichester.

Nikitin, N. I. (1962). Chemistry of Wood and Cellulose, No ISBN, Nauka, Leningrad, Russia, (in Russian)

Paradossi, G., Chiessi, E., Cavalieri, F. et al. (1998). Networks Based on Chitosan and Oxidized Cyclodextrin-II. Structure and Catalytic Features of a Copper (II)-loaded Network. Polym. Gels \& Networks, Vol. 5, No.6, (April 1998), pp. 525-54, ISSN 0966-7822

Parshina, E.V., Molochnikov, L.S., Kovaleva, E.G. et al. (2011). Medium Acidity and Catalytic Properties of Composite Materials Based on Silica and Titanium and Powder Cellulose in the Presence of $\mathrm{Cu}^{2+}$ Ions. Russ. J. Phys. Chem. A,Vol. 85, No.3 , (March 2011), pp. 452-456, ISSN 0036-0244

Parshina, E.V. (2011) Acid-base, Complexation and Catalytic Properties of Solid Phase Composits Based on Ddioxide Elements Xerogels and Powder Cellulose, Ph. D. Dissertation in Chemistry, Ural State Forest Engineering University, Yekaterinburg, Russia (defended at the Chelyabinsk State Pedagogical University, Chelyabinsk) (in Russian)

Petrov, L.A., Kharchuk, V.G., Shishmakov, A.B. et al. (1998). Oxidation of 2,3,6-Trimethyl1,4-Benzenediol by Oxygen in the Presence of Oxide Gels . Russ. J. Org. Chem. , Vol. 34, No. 7, (July 1998), pp. 344-346, ISSN 1070-4280

Poznyak, S.K., Pergushov, V.I., Kokorin, A.I., et al. (1999). Structure and Electrochemical Pproperties of Species Formed as a Result of $\mathrm{Cu}(\mathrm{II})$ ions Absorption onto $\mathrm{TiO}_{2}$ Nanoparticles. J. Phys. Chem., B, 1999, Vol. 103, No.8, (February 1999), pp. 1308 - 1515, ISSN 1520-6106 
Robinson, M., Pask, J.A. \& Fuerstenau, D.W. (1964). Surface Charge of Alumina and Magnesia in Aqueous Media. J. Am.Ceram. Soc., Vol. 47, pp. 516-520, No. 10, (October 1964), ISSN 1551-2916

Senso, A., Oliveros, L. \& Minguillon, C. (1999). Chitosan Derivatives as Chiral Selectors Bonded on Allyl Silica Gel : Preparation, Characterization, and Study of the Resulting High-PerformanceLiquid Chromatography Chiral Stationary Phases. J. Chromatogr., A, Vol. 839, No.1, (April 1999), pp.15-21, ISSN 0021-9673

Silva, R.B., Neto, A.F., Santas, L.S. et al .(2008). Catalysts of Cu(II) and Co(II) Ions Adsorbed in Chitosan Used in Transesterification of Soy Bean and Babassu Oils - A New Route for Biodiesel Syntheses. Biores. Technol., Vol.99, pp.6793-6798, No.15, (October 2008), ISSN 0960-8524

Shi, Q.-H. , Tian, Y., Dong, X.-Y. et al. (2003). Chitosan-Coated Silica Beads as Immobilized Metal Affinity Suppor for Protein Adsorption. Biochem. Eng.J. Vol.16, No.3, ( December 2003), pp. 317- 322, ISSN 1369-703X

Shishmakov, A.B., Kharchuk, V.G., Kuznetsova, O.V., et al. (2003). Activity of Elements Dioxides in liquid Phase Oxidation of 2,3,5-trimethyl Hydroquinone. Zh. Fiz. Khim. (Rus. J. Phys. Chem.), Vol. 77, pp. 623-628, ISSN 0036-0244 (in Russian)

Shishmakov, A. B., Mikushina, Yu. V., Valova, M. S. et al. (2007). $\mathrm{TiO}_{2}$ Xerogel Modified with Powder Cellulose in Oxidation Trimethylhydroquinone. Russ. J. Appl. Chem., Vol.80, No.12, (December 2007), pp. 2107-2111, ISSN 1070-4272

Shishmakov, A.B., Kovaleva, E.G.., Mikushina,Yu.V. et al. (2010). EPR study of Cu(II)Complexes in Matrix of the $\mathrm{TiO}_{2}$ Gel Modified with Powder Cellulose. Russ. J. Inorg. Chemistry, Vol. 55, No.6, pp. 937-942, ISSN 0036-0236

Skorik, Yu. A., Gomes, C. A. R., Teresa,. M. , Vasconcelos, S. D. et al. (2003). N-(2Carboxyethyl) Chitosans: Regioselective Synthesis, Characterization and Protolytic Equilibruia. Carbohydr. Res. , V.338, No.3, (January 2003), pp. 271-276, ISSN 0008-6215

Ur'ev, N. B. \& Potanin, A. A. (1992). Tekuchest' suspenzi' i poroshkov (Fluidity of Suspensions and Powders) Khimiya (Chemistry), ISBN 5724506572, Moscow (in Russian)

Varghese, J. G., Karuppannan, R. S. \& Kariduraganavar, M. Y. (2010). Development of Hybrade Membranes Using Chitosan and Silica Precursors for Pervaporation Separation of Water + Isopropanol Mixtures. J. Chem. Eng. Data, Vol. 55, No.6, (June 2010), pp. 2084-2092, ISSN 0021-9568

Varma, A. J. , Deshpande, S. V.\& Kennedy, J. F. (2004). Metal Complexation by Chitosan and Its Derivatives: A Review. Carbohydr. Polym. Vol. 55, No.1, (January 2004), pp. 77-93, ISSN 0144-8617

Viswanathana, N. \& Meenakshib, S (2010). Enriched Fluoride Sorption Using AluminaChitosan Composite. J. Hazard. Mater. Vol. 178, No.1, (June 2010), pp. 226-232, ISSN 0304-3894

Voinov, Maxim A., Kirilyuk, Igor A. \& Smirnov, Alex I. (2009). Spin-Labeled pH-Sensitive Phospholipids for Interfacial pK Determination: Synthesis and Characterization in Aqueous and Micellar Solutions. J. Phys. Chem. B, Vol.113, No. 11, (March 19, 2009), pp.3453-3460, ISSN ISSN 1520-6106 
Volodarskii, L.B., Grigor'ev, I.A., Dikanov, S.A. et al. (1988). Imidazolinovye Nitroksil'nye Radikaly (Imidazoline Nitroxyl Radicals), Nauka, ISBN 5-0028677-X, Novosibirsk (in Russian)

Xue, L., Zhou, D.-J., Tang, L. et al. (2004). The Asymmetric Hydration of 1-octene to (S)-(+) With a Biopolymer-Metal Complex, Silica-Supported Chitosan-Cobalt Complex. React. Funct. Polym. Vol.58, No. 2, (February 2004), pp. 117 - 121 , ISSN 1381-5148

Yeh, J. Chen, C. \& Huang, K. (2007). Synthesis and Properties of Chitosan/SiOz Hybride Materials. Mater. Lett. ,Vol. 61, No.6, (March 2007), pp.1292- 1295.,ISSN 0167-577X

Zakharova, G.S., Volkov, V.L., Ivanovskaya, V.V. et.a 1. (2005). Nanotrubki i Rodstvennye Nanostruktury Oksidov Metallov (Nanotubes and Related Nano-structures of Metal Oxides), Ural. Otd. Ross. Akad. Nauk (Ural Branch of the Russian Academy of Sciences), ISBN 57691-1559-9, Yekaterinburg (in Russian)

Zamaraev, K.I., Salganik, R.I., Romannikov, V.N. et al. (1995). Modeling of Prebiotic Oligopeptides in the Presence of Zeolites and Kaolin as Catalysts. Dokl. Akad. Nauk (Reports of Academy of Sciences), Vol. 340, p. 779-782, ISSN 0869-5652 (in Russian)

Zhang, J. \& Xia, C. (2003). Natural Biopolymer-Supported Bimetallic Catalyst Ssystem for the Carbonylation to Esters of Napoxen. J. Mol. Catal. A: Chem. Vol.206, No.1, (October 2003 ), pp. 59-65, ISSN 0021-9517

Zhao, X. S. \& Lu, G. Q. (1998). Modification of MCM-41 by Surface Silylation with Trimethylchlorosilane and Adsorption Study. J. Phys. Chem. B, Vol. 102, No.9, (February 1998), pp.1556-1561, ISSN 1520-6106

Zhao, X. S., Lu, G. Q., Whittaker, A. K. et al. (1997). Comprehensive Study of Surface Chemistry of MCM-41 Using ${ }^{29}$ Si CP/MAS NMR, FTIR, Pyridine-TPD and TGA. J. Phys. Chem. B, V. 101, No.33, pp. 6525-6531, ISSN 1520-6106 